\title{
Equity in distribution of hospital beds in Iran
}

\author{
Alimohammad Mosadeghrad ${ }^{1}$, Ghasem Janbabaei ${ }^{2}$, Behzad Kalantari ${ }^{3}$, Alireza Darrudi ${ }^{4}$, $\underline{\text { Hamed }}$ \\ Dehnavi $^{5}$ \\ 1. Associate Professor, Health Management and Economics Department, School of Public Health, Health Information \\ Management Research Center, Tehran University of Medical Sciences, Tehran, Iran. ORCID ID: 0000-0002-7955-6292 \\ 2. Associate Professor, Oncology and Hematology Department, Tehran University of Medical Sciences, Tehran, Iran. \\ ORCID ID: 0000-0003-2651-6200 \\ 3. MD-MBA-MPH, Hospital management and organizational excellence department, Ministry of Health and Medical \\ Education, Tehran, Iran. ORCID ID: 0000-0003-0069-2783 \\ 4. Ph.D Student in Health Economics, Health Management and Economics Department, School of Public Health, Tehran \\ University of Medical Sciences, Tehran, Iran. ORCID ID: 0000-0002-5811-2166 \\ 5. Ph.D Student in Health Care Management, Health Management and Economics Department, School of Public Health, \\ Tehran University of Medical Sciences, Tehran, Iran, (Corresponding Author), Tel: 021-42933006, Email: \\ hamedehnavi@gmail.com. ORCID ID: 0000-0002-8183-4458
}

\begin{abstract}
Background and Aim: Equitable distribution of health system resources and hospital beds is crucial for an acceptable level of health for all the people of the country. The aim of this study was to examine the equity in distribution of hospital beds in Iran.

Materials and Methods: In this descriptive and cross sectional study data were collected from Ministry of Health and Medical Education and Iranian statistics Center. The study population consisted of all Iranian hospitals in 2016. The equity in the distribution of hospitals' beds was evaluated using the Lorenz curve and Gini coefficient. Excel software was used for data analysis.

Results: Iranian population was 79,926,270 and there were 930 hospitals with 118,894 beds in 2016. (1.2 hospitals per 100,000 population and 1.5 hospital beds per 1000 population). Yazd, Semnan and Tehran provinces had the highest hospital beds per 1000 population. About $17 \%$ of the total hospitals and $22 \%$ of the hospital beds were located in Tehran. The Gini coefficient for hospital bed distribution among Iranian provinces was 0.107. Distribution of the hospital beds was equitable in Alborz and Yazd provinces and inequitable in North Khorasan, Sistan \& Baluchestan and Charmahal \& Bakhtiary provinces.

Conclusion: The distribution of hospital beds among Iranian provinces has been fair. However, hospital beds were not distributed equitably among the cities in the provinces and were concentrated in the capital cities of the provinces of the country. Healthcare policymakers should take appropriate measures to reduce inequality in the distribution of hospital beds.
\end{abstract}

Keywords: Hospital, Resource allocation, Hospital bed distribution, Gini coefficient, Equity

Received: Jan 7, 2019

Accepted: Oct 15,2019

How to cite the article: Alimohammad Mosadeghrad, Ghasem Janbabaei, Behzad Kalantari, Alireza Darrudi, Hamed Dehnavi. Equity in distribution of hospital beds in Iran. SJKU 2020; 24 (6): 12-36

Copyright (C) 2018 the Author (s). Published by Kurdistan University of Medical Sciences. This is an open access article distributed under the terms of the Creative Commons Attribution-Non Commercial License 4.0 (CCBYNC), where it is permissible to download, share, remix, transform, and buildup the work provided it is properly cited. The work cannot be used commercially without permission from the journa 


\section{عدالت در توزيع جغر افيايى تختهاى بيمارستانى در ايران}

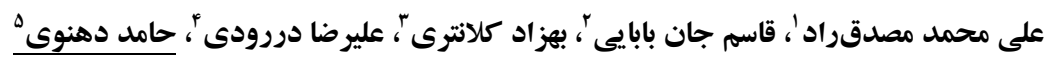

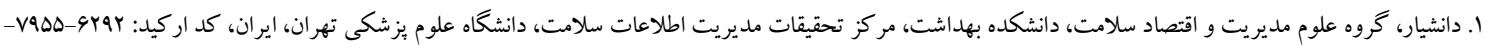

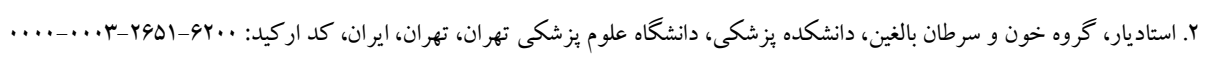

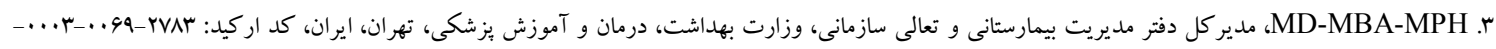

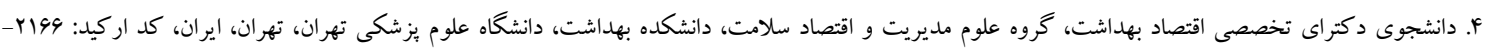

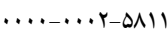

ه. دانشجوى دكتراى تخصصى مديريت خدمات بهداشتى و درمانى، گروه علوم مديريت و اقتصاد سلامت، دانشكده بهداشت، دانشكاه علوم يزشكى تهران، تهران، ايران،

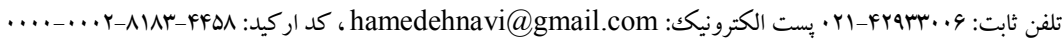

جكيله

زمينه و هدف: توزيع عادلانه تختهایى بيمارستانى تأثير بسزايى بر دسترسى به خدمات سلامت و سلامتى مردم جامعه دارد. اين يُزوهش با هدف سنجش عدالت در توزيع جغرافيايى تختهاى بيمارستانى ايران انجام شده است.

روش بررسى: براى انجام اين بزّوهش توصيفى و مقطعى از دادهاى وزارت بهداشت، درمان و آموزش بزشكى و مركز آمار ايران استفاده شد. جامعه مورد مطالعه شامل تمام بيمارستانهاى ايران در سال هوسا است. ميزان عدالت در توزيع تختهاى بيمارستانى كشور با استفاده از منحنى لورنز و ضريب جينى تعيين و محاسبه شد. از نرم افزار اكسل براى تحليل دادهها استفاده شد.

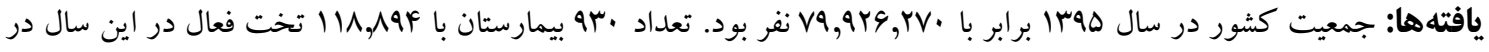
كشور وجود داشت (تعداد ك/ إيمارستان به ازاى هر صد هزار نفر جمعيت و ال تخت بيمارستانى به ازاى هر هزار نفر جمعيت). بيشترين تعداد تخت بيمارستانى به ازاى هزار نفر جمعيت مربوط به استانهاى يزد، سمنان و تهران بوده است. حدود IV درصد بيمارستانها و r r درصد تختهاى بيمارستانى كشور در استان تهران بود. ضريب جينى توزيع تختهاى بيمارستانى در استانهاى كشور برابر با V• / • بوده است. تختهاى بيمارستانى در استانهاى البرز و يزد به صورت عادلانه و در استانهاى خراسان شمالى، سيستان و بلوجستان و جهارمحال و بختيارى تا حدودى ناعادلانه توزيع شده است. نتيجهَيرى: توزيع تختهاى بيمارستانى در استانهاى ايران نسبتاً عادلانه بوده است. با اين وجود، تختهاى بيمارستانى بيشتر در مراكز استانها متمركز شده و در شهرستانهاى استانها بهصورت عادلانه توزيع نشدند. سياست گذاران و مديران ارشد نظام سلامت بايد اقداماتى براى بهبود عدالت در دستر سى مردم جامعه به تختهاى بيمارستانى بكار گيرند. كلمات كليدى: بيمارستان، تخصيص منابع، توزيع تخت بيمارستانى، ضريب جينى، عدالت

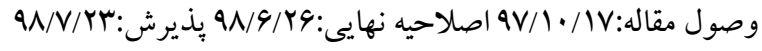


بنابراين، عدالت در نظام سلامت به دو دسته عدالت افقى Equity) و عدالت عمودى (انصاف) Equality قابل تقسيم است. در عدالت افقى سعى مىشود تا با همه افراد داراى نياز يكسان، به طور برابر رفتار شود. وليكن، بايد توجه داشت كه نيازهاى مردم در نظام سلامت برابر نيست؛ بنابراين، در عدالت عمودى سعى مىشود تا با همه افراد متناسب با نيازهاى آنها، عادلانه و منصفانه رفتار شود. عدالت در نظام سلامت شامل سه حوزه تأمين مالى خدمات سلامت (توانايى يرداخت هزينههاى خدمات سلامت)، ارائه خدمات سلامت (دسترسى به خدمات سلامت) و و سطح سلامتى مردم (برخوردارى از سلامت) است؛ بنابراين، عدالت در نظام سلامت عبارت است از دسترسى مردم به خدمات سلامت و استفاده از آن بر اساس نياز، برداخت هز ينههاى خدمات سلامت بر اساس توان مالى و برخوردارى

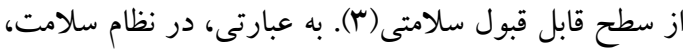
افرادى كه نياز بيشترى به خدمات سلامت دارند، بايد از خدمات سلامت بيشترى استفاده كند؛ افراد با توان يرداخت بيشتر، مشاركت بيشترى در برداخت هزينهاى سلامت

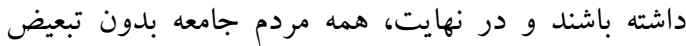

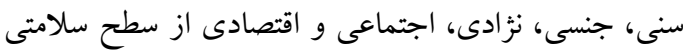
برابرى برخوردار باشند. به همين دليل، اصلاحات نظام سلامت در كشورهاى توسعه يافته بيشتر بر افراد محروم جامعه كه نياز بيشترى به خدمات سلامت دارند، متمركز شده

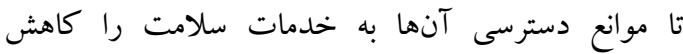

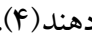

اكرجّه دولتها اقداماتى براى تضمين عدالت در نظام

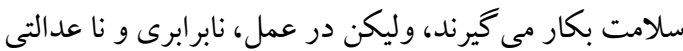
در تأمين مالى، دسترسى و استفاده از خدمات سلامت و وضعيت سلامتى بين گروههاى مختلف جمعيتى به ويزه اقشار آسيبِيذير جامعه مشاهده مىشود. به عنوان مثال،

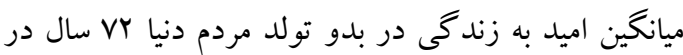

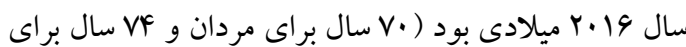

مقدمه

نظام سلامت شامل سازمانها، مؤسسات، گروهها و افرادى

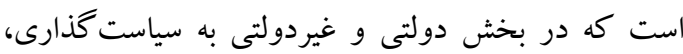
توليد منابع، تأمين مالى و ارائه خدمات سلامت فردى و عمومى با هدف بازيابى، ارتقاء و حفظ سلامتى مردم مى يردازند. سه هدف اصلى نظام سلامت عبارتاند از تأمين، حفظ و ارتقاى سلامتى مردم جامعه؛ باسخ گويى به به انتظارات مردم و حمايت مالى از آنها در مقابل هزينههاى سلامت. همجنِين، دسترسى، ايمنى، كيفيت، كارايى، عدالت و تاب آورى بهعنوان اهداف واسطهاى نظام سلامت، يِشنياز

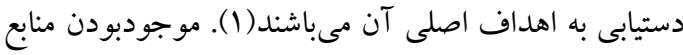
نظام سلامت نقش بسزايى در عدالت و كارايى نظام سلامت و دستيابى به اهداف اصلى آن دارد. با اين وجود، توزيع عادلانه منابع سلامت نظير تختهاى بيمارستانى، بزشكان و يرستاران در جامعه، بِيش نياز دستيابى همه مردم به سطح

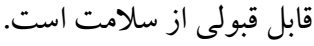

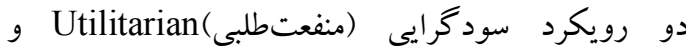
تساوى گرايى (مساوات طلبى) Egalitarian در زمينه تخصيص منابع وجود دارد. بر اساس رويكرد منفعتطلبى، منابع سلامت بايد به گونهاى در جامعه توزيع شود كه بيشترين منفعت و مطلوبيت را براى تعداد بيشترى از افراد جامعه به دنبال داشته باشد و سلامتى و رفاه را براى مردم جامعه حداكثر كند؛ بنابر اين، مبناى قضاوت براى تخصيص

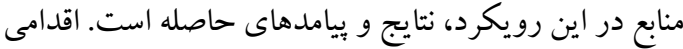
كه بيشترين منفعت را براى بيشترين افراد جامعه به دنبال داشته باشد، يكك اقدام اخلاقى محسوب مىشود. در مقابل، بر اساس رويكرد مساوات طلبى، همه مردم با هم برابر هستند

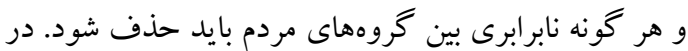
نتيجه، تخصيص منابع در اين رويكرد متوجه اقشار آسيبذيذير نيازمند كه ممكن است تعدادشان در جامعه كم

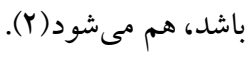


خدمات بيمارستانى، به كارگيرى كاركنان تخصى

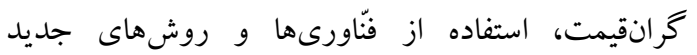
تشخيصى و درمانى و بروز خطاهاى بز شكى منجر به افزايش هزينهاى بيمارستانى شده است(سا). در نتيجه، بيمارستانها بخش قابلتوجهى از بودجه نظام سلامت را به خود

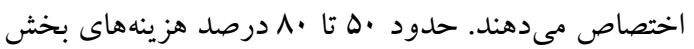
سلامت دولت در كشورهاى در حال توسعه، به بيمارستانها تخصيص يافته است( هاو \& ()؛ بنابراين، توزيع بيمارستانها و تخت هاى بيمارستانى بايد متناسب با نياز مردم جامعه صورت

عوامل متعددى نظير كميت و كيفيت جمعيت، بار بيمارىها و روندهاى اييدميولوزيكك، يروتكلهاى درمانى، روش يرداخت سازمانهاى بيمه سلامت، رقابت بين ارائه كنند گان خدمات بيمارستانى و موجود بودن تسهيلات جايخزين مراقبتهاى بيمارستانى بر تعداد تختهاى بيمارستانها اثر مى كذارد. شاخص تعداد تخت بيمارستانى به ازاى هر هزار نفر جمعيت يكى از شاخص هاى مهم ارائه خدمات سلامت است. با اين وجود، تعداد زياد تخت بيمارستانى در يك كشور به تنهايى منجر به بهبود وضعيت سلامتى مردم نمىشود. توزيع عادلانه تختهاى بيمارستانى هم حائز اهميت است كه تأثير قابل توجهى بر سلامتى مردم جامعه دارد؛ بنابراين، اين يثوهش با هدف سنجش عدالت در توزيع جغرافيايى تختهاى بيمارستانى در ايران انجام شده است. نتايج اين يثروهش، اطلاعات ارزشمندى را در اختيار سياست گذاران و مديران ارشد نظام سلامت ايران به منظور مديريت صحيح تختهاى بيمارستانى كشور قرار مىدهد.

\section{روش بروسى}

اين يزوهش از نوع توصيفى بوده كه براى اجراى آن از اطلاعات كذشته استفاده شده است. دادههاى مربوط به تعداد، نوع، تخصص، مالكيت و سال تأسيس بيمارستانهاى
زنان). تفاوت بين طول عمر زنان و مردان f سال بوده است. همجنين، تفاوت زيادى بين اميد به زندكى مردم كشورهاى مختلف جهان مشاهده مىشود. به عنوان مثال، اختلاف اس سال بين اميد به زندگى مردم زاين (NF سال) و مردم سر الئون (rه سال) وجود دارد(ه). كود كان مناطق شهرى از سلامتى بهترى نسبت به كودكان روستايى برخوردار هستند(4). ميزان مرگك كود كان زير ه سال در مناطق روستايى بيشتر از مناطق شهرى است(V). همجيجين، ميزان سوء تغذيه در كودكان روستايى بيشتر از كودكان شهرى است(^). مطالعهاى نشان داد كه شيوع سوء تغذيه در كود كان زير ه سال با مادر بىسواد، حدود ها درصد بيشتر از كود كان داراى مادر با سواد بود(V). بنابراين، سياست كذاران و مديران ارشد نظام سلامت به هنگام تخصيص منابع بايد اطمينان حاصل كنند كه همه مردم جامعه به هنگام نياز، دسترسى عادلانه به خدمات سلامت دارند. در نتيجه، توزيع عادلانه منابع سلامت بسيار حائز اهميت است. ويز گیىهاى اجتماعى، اقتصادى و فرهنكى مردم بر استفاده آنها از خدمات سلامت اثر مى گذارد. تحصيلات بالا، استخدام و درآمد بالا، منجر به دسترسى بهتر مردم به خدمات سلامت و در نتيجه بهبود سلامتى آنها مىشود. مطالعات قبلى نشان داده است كه مردم طبقات اجتماعى و اقتصادى پِيين جامعه دسترسى كمترى به منابع سلامت نسبت به مردم ساكن در نواحى توسعه يافته دارند(·1 و 9). به عنوان مثال، مطالعهاى در كانادا نشان داد كه افراد با تحصيلات و درامد يايين، تعداد ويزيت يزشك متخصص بسيار كمترى در طول يكك سال

داشتند(·) (1).

بيمارستان يكى از مهمترين اجزاى نظام سلامت است كه وظيفه ارائه خدمات تشخيصى، درمانى و بازتوانى با كيفيت، ايمن، اثربخش و كار آمل رابه منظور تأمين، حفظ و ارتقاى سلامتى مردم جامعه بر عهلده دارد(باو ||(1). افزايش جمعيت سالمند، افزايش بيمارىهاى مزمن، تقاضاى روزافزون براى 
آموزش يزشكى دريافت شد(1)). دادههاى مربوط به

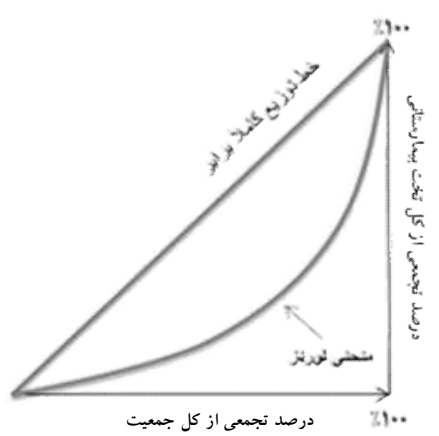

نمودار ا. منحنى لورنز

در اين فرمول G ضريب جينى، Xi نسبت تجمعى جمعيت، نسبت تجمعى تخت فعال بيمارستانى و Ki استانها است. ضريب جينى بين صفر و يك متغير است. ضريب جينى صفر (انطباق منحنى لورنز با خط ها درجه) اشاره به توزيع كاملاً برابر منابع و ضريب جينى يك حاكى از نابرابرى كامل در توزيع منابع است. هر قدر ضريب جينى به سمت صفر ميل كند، بيانگر توزيع عادلانه منابع در جامعه است. ضريب جينى بيش از \&/· بيانگر نابرابرى تخصيص منابع بوده و نخر ان كننده است. دادهها با استفاده از نرم افزار EXCEL

فرمول محاسبه ضريب جينى در اين مطالعه عبارت است از:

$$
G=1-\sum_{i=0}^{k-1}\left(y_{i+1}+y_{i}\right)\left(x_{i+1}-x_{i}\right)
$$

بيمارستانهاى بانككها (11/ • درصد) و آموزش و برورش (II/ • درصد) كمترين بيمارستانهاى كشور را تشكيل دادند. بيمارستانهاى دانشگاهى بيشترين تخت بيمارستانى كشور (99 درصد) را در اختيار داشتند (جدول ().
كشور و تعداد تخت آنها از وزارت بهداشت، درمان و جمعت هر استان و شهرستان از سرشمارى نفوس و مسكن سال هوبا مركز آمار ايران استخراج شد(IV). در اين مطالعه از شاخص ضريب جينى براى سنجش عدالت در توزيع جغرافيايى تختهاى بيمارستانى استفاده شد كه ير كاربردترين شاخص نابرابرى است(19|و1). ضريب جينى در سال 191r ميلادى توسط آماردان و جامعه شناس ايتاليايى، كورادو جينى Corrado Gini ابداع شد(·). ضريب جينى از منحنى لورنز استخراج مىشود كه توسط ماكس لورنز Max Otto Lorenz اقتصاد دان آمريكايى در سال هـ •19 ميلادى براى نشان دادن نابر ابرى توزيع ثروت در جامعه توسعه داده شد(Y). در اين نمودار خط درجه، توزيع برابرى كامل در آمدها را نشان مىدهد. هر قدر فاصله منحنى لورنز از اين خط برابرى بيشتر باشد، نابرابرى در توزيع منابع بيشتر است. شاخص جينى نسبت مساحت بين خط برابرى و منحنى لورنز و مساحت كل زير خط برابرى است. در اين مطالعه، محور X درصد تجمعى جمعيت و محور Y درصد تجمعى تختهاى بيمارستانى را در نمودار منحنى لورنز تشكيل دادند (نمودار ()).

\section{يافته ها}

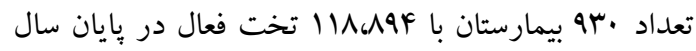
هوسا در كشور وجود داشت. بيمارستانهاى دانشخاهى

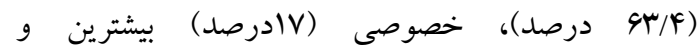


جدول ا. بيمارستانها و تخت هاى بيمارستانى ايران به تفكيك نوع مالكيت در سال هوب|

\begin{tabular}{|c|c|c|c|c|}
\hline \multicolumn{2}{|c|}{ تخت فعال } & \multicolumn{2}{|c|}{ بيمارستان } & \multirow[t]{2}{*}{ نوع سازمان } \\
\hline درصد & تعداد & درصد & ت تعداد & \\
\hline $9 \wedge / \mu q$ & $\wedge 1, r 1$. & $G M / F F$ & $\Delta q$. & دانشكاه علوم يزشكى \\
\hline $\mid r / A \Lambda$ & $|0, r| 1$ & $19 / 99$ & 101 & بخش خصوصى \\
\hline$N / \Delta r$ & $1 \cdot$, ITr & $V / g r$ & vi & سازمان تأمين اجتماعى \\
\hline$F / M r$ & $F, \wedge 90$ & $F / V r$ & FF & نيروهاى مسلح \\
\hline$r / 4 r$ & $F, \cdot v q$ & $\mathrm{r} / \mathrm{AV}$ & re & سازمانهاى خيريه \\
\hline$\cdot / \mathrm{Q} 9$ & ars & $1 / \cdot 1$ & 1. & بنياد شهيد و امور ايثارگران \\
\hline$\cdot / \wedge 1$ & $9 \Delta 9$ & $\cdot / 9 V$ & 9 & شركت نفت \\
\hline$\cdot / A T$ & $\Delta .$. & $\cdot / \mathrm{V} \Delta$ & $\checkmark$ & دانشكاه آزاد اسلامى \\
\hline .190 & Wr & $\cdot / \Delta F$ & $\Delta$ & ساير سازمانها \\
\hline $1 \cdots$ & 111498 & $1+\cdot$ & $q r$. & كل - ل \\
\hline
\end{tabular}

بيمارستان در هر مركز استان) و FF4 بيمارستان در شهرستانها (يكك بيمارستان در هر شهرستان) كشور وجود

$$
\text { داشت (جدول). }
$$

طبق گزارش مركز آمار در سال هوبا تعداد اس استان، FYq شهرستان و سF ا شهر در ايران وجود داشت(ها). بيشتر بيمارستانها و تختهاى بيمارستانى در مراكز استانها قرار داشتند. تعداد FAF بيمارستان در مراكز استانها (ميانگين 19

جدول r. بيمارستانها و تخت هاى بيمارستانى ايران به تفكيك محل تأسيس در سال هوسا

\begin{tabular}{|c|c|c|c|c|c|c|c|c|}
\hline \multicolumn{4}{|c|}{ شهرستانها } & \multicolumn{4}{|c|}{ مراكز استانها } & \multirow{3}{*}{ نوع سازمان } \\
\hline \multicolumn{2}{|c|}{ تخت فعال } & \multicolumn{2}{|c|}{ بيمارستان } & \multicolumn{2}{|c|}{ تخت فعال } & \multicolumn{2}{|c|}{ بيمارستان } & \\
\hline درصد & تعداد & درصد & تعداد & درصد & تعداد & درصد & تعداد & \\
\hline$\Lambda V / 94$ & $M F, 191$ & $\Lambda \Delta / Y$. & rی. & $\Delta \wedge / 99$ & $F V, I F q$ & $k r / \mu q$ & rl. & دانشكاه علوم يز شكى \\
\hline r/Vr & $1, \cdot 9$ & $r / \Delta 9$ & 19 & IV/Ar & $|F, Y \Delta|$ & $r Q / \mu r$ & IFr & بخش خصوصى \\
\hline.$/ 10$ & $\Delta \Lambda$ & $\cdot 19 \mathrm{~V}$ & $r$ & $9 / \cdot 0$ & $F, \wedge r V$ & $N / \& V$ & Fl & نيروهاى مسلح \\
\hline $9 / 9 \pi$ & $r, \Delta \wedge \Delta$ & $9 / 90$ & $\mu$ & $9 / F F$ & $V, \Delta F V$ & $N / Y^{4}$ & f. & سازمان تأمين اجتماعى \\
\hline$\cdot / 94$ & rol & $\cdot / 9$ & f & $F / v a$ & $r, \wedge r \wedge$ & $9 / 91$ & rr & سازمانهاى خيريه \\
\hline . $/ 4 r$ & 194 & $\cdot / \& \Delta$ & r & $\cdot / 9 V$ & Wr & $1 / 90$ & $\wedge$ & بنياد شهيد و امور ايثارگران \\
\hline$\cdot / 49$ & $1 \ldots$ & $\cdot / \& \Delta$ & r & $\cdot / 0$ & $4 .$. & $1 / \cdot r$ & $\Delta$ & دانشگاه آزاد اسلامى \\
\hline $1 / .9$ & FIF & $1 / \pi \Delta$ & 9 & $\cdot 191$ & $\Delta F \Delta$ & .194 & $r$ & شركت نفت \\
\hline$\cdot / 49$ & IVA & $\cdot / 4 \Delta$ & r & $\cdot / V^{F}$ & $\Delta q F$ & $\cdot 194$ & $r$ & ساير سازمانها \\
\hline $1 \cdots$ & rᄉ,qri & $1 \cdots$ & pfs & $1 \cdots$ & vq,qrr & $1 \cdots$ & PAP & كل \\
\hline
\end{tabular}

حدود ها\&\% تختهاى موجود در كشور در بيمارستانهاى

آموزشى، درمانى و يزٔوهشى قرار گر فته است (جدول).

بيمارستانهاى درمانى درمانى و بزثوهشى 19/9٪ بيمارستانها را تشكيل مىدادند. 
جدول r. بيمارستانها و تخت هاى فعال بيمارستانى به تفكيكك مأموريت در سال هه؟ा

\begin{tabular}{|c|c|c|c|c|}
\hline \multicolumn{2}{|c|}{ تخت فعال } & \multicolumn{2}{|c|}{ بيمارستان } & \multirow{2}{*}{ مأموريت بيمارستان } \\
\hline درصد & تعداد & درصد & تعداد & \\
\hline$\Delta F / V I$ & $90,+19$ & $V M / F F$ & 9ᄉr & درمانى \\
\hline$r \Delta / r q$ & $\Delta r, \lambda F \Delta$ & rQ/09 & YFV & آموزشى، درمانى و بُزوهشى \\
\hline $1 \cdots$ & 111494 & $1 \cdots$ & q. & 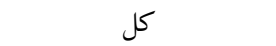 \\
\hline
\end{tabular}

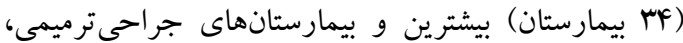
اورولوزى و وبوست هر كدام با يكك بيمارستان، كمترين بيمارستانهاى تخصصى كشور بودند (جدول\&).
حدود A9.٪ بيمارستانهاى كشور عمومى و If درصد

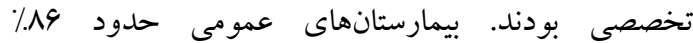
تختهاى فعال بيمارستانى كشور را در اختيار داشتند. بيمارستانهاى روانيزشكى (ها بيمارستان) و زنان و زايمان

\begin{tabular}{|c|c|c|c|c|}
\hline \multicolumn{2}{|c|}{ تخت فعال } & \multicolumn{2}{|c|}{ بيمارستان } & \multirow{2}{*}{ نوع ارائه خدمت } \\
\hline درصد & تعداد & درصد & تعداد & \\
\hline$\Lambda \Delta / 9 \Delta$ & $1.1, \lambda r r$ & $\Lambda \Delta / \Delta Q$ & va9 & عمومى \\
\hline $0 / .9$ & $9, \cdot \Delta \Delta$ & r/ve & ro & روانيزشكى \\
\hline$r / 4$. & $r, \wedge \Delta G$ & $r / 99$ & $r F$ & زنان و زايمان \\
\hline$r / \cdot$ & r, rVG & l/Ar & IV & اطفال \\
\hline$Y / .9$ & r, FAS & $1 / 19$ & ir & قلب \\
\hline .194 & $V * 1$ & $1 / r^{2}$ & ir & جشم \\
\hline$\cdot|\Lambda|$ & 991 &.$/ 9 V$ & 9 & سوانح و سوختكى \\
\hline$\cdot / \Delta r$ & $9 \pi$ & $\cdot / \mathrm{VQ}$ & $\checkmark$ & سرطان و انكولوزى \\
\hline$\cdot / \Delta r$ & 949 & $\cdot / \Delta F$ & $\Delta$ & ارتويدى \\
\hline .1 .9 & $1 . r$ &.$/ 11$ & 1 & جراحى - ترميمى \\
\hline$\cdot / M r$ & 149 &.$/ 11$ & 1 & اورولوزى \\
\hline .1 .9 & 99 &.$/ 11$ & 1 & يوست \\
\hline $1 \cdots$ & l11494 & $1 \ldots$ & qr. & كل \\
\hline
\end{tabular}

علوم يزشكى رشد بالاترى در ساخت بيمارستان نسبت به ساير بخش ها داشته است. دانشگًاههاى علوم يزشكى در سال

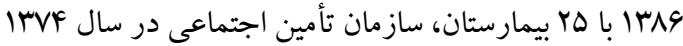

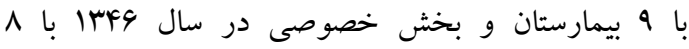
بيمارستان، بيشترين بيمارستانهاى كشور را تأسيس كردند. بيشترين تعداد تختهاى كشور در سال •^شا ايجاد شدند
در خصوص روند سال تأسيس بيمارستانهاى كشور؛ سالهاى ITVA بيمارستانسازى در ايران بود (نمودارب). همانطور كه در نمودارس نشان داده شده است، در اين سالها توليد ناخالص داخلى ايران افزايش جشمخيرى داشته است. دانشگاههاى 
بيشترين تختهاى بيمارستانى كشور را ايجاد كردند

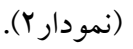

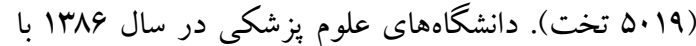

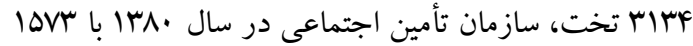
تخت و بخش خصوصى در سال ITVA با بV VYF

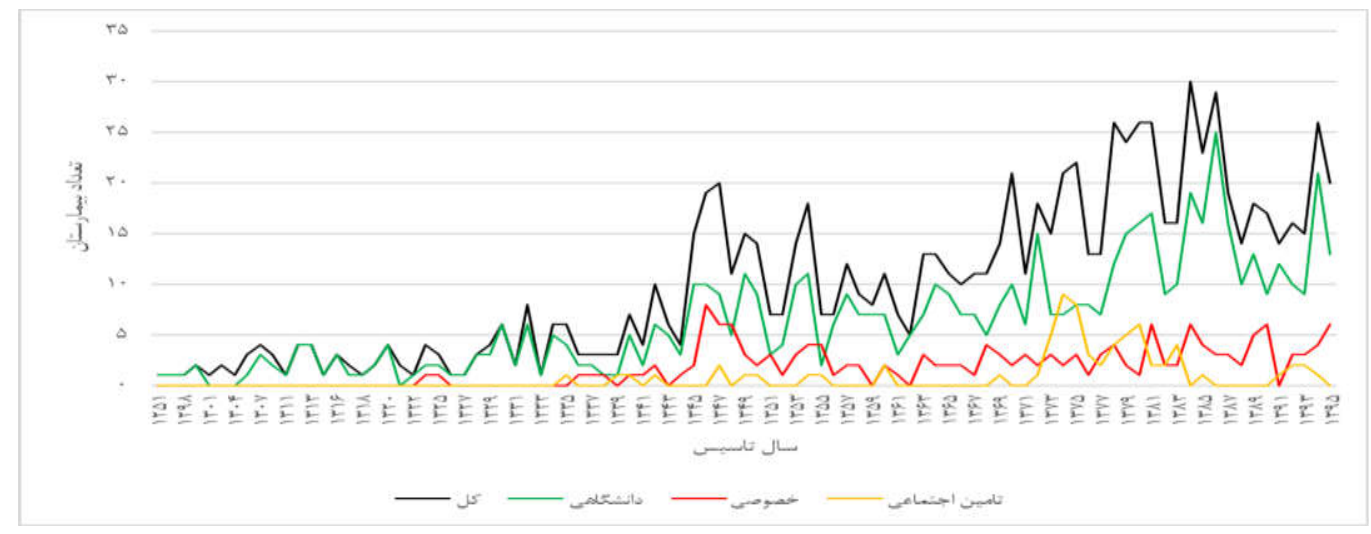

نمودار ז. روند سال تأسيس بيمارستانهاى ايران به تفكيك مالكيت در سال هوب|

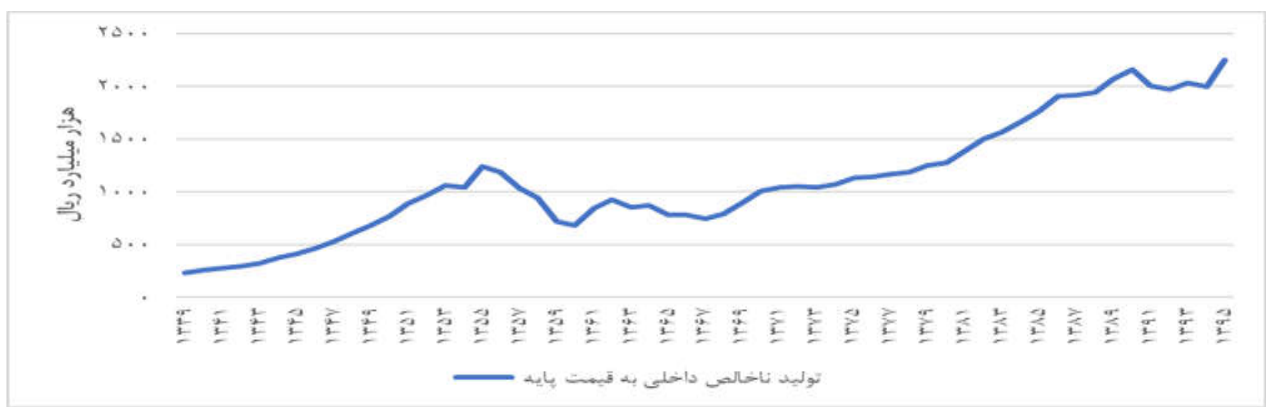

نمو دارّا. روند توليد ناخالص داخلى ايران (به قيمتهاى ثابت سال شیץ|)

در جريان اجراى طرح تحول نظام سلامت يعنى از سال

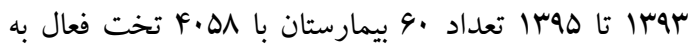
ظرفيت بيمارستانى كشور اضافه شد.

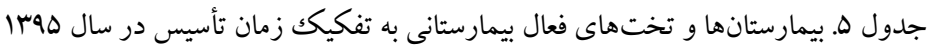

\begin{tabular}{|c|c|c|c|c|}
\hline \multicolumn{2}{|c|}{ تخت فعال } & \multicolumn{2}{|c|}{ بيمارستان } & \multirow{2}{*}{ دها } \\
\hline درصد & تعداد & درصد & تعداد & \\
\hline IY/VA & $10,19$. & $11 / 9 F$ & 111 & دهם . \\
\hline $1 Y / 99$ & $10, \cdot \wedge r$ & $11 / \cdot 1$ & $1 \cdot r$ & دهם •טr| \\
\hline IY/TF & 11,999 & $11 / F$. & 1.9 & دهם .9 114 \\
\hline$|1 / 1|$ & rl, $\Delta r q$ & $19 / \mathrm{VA}$ & INF & دهם •VVI \\
\hline (Tr/T & $r q, \Delta V I$ & سז/Mr & YIV & دهם •N| \\
\hline G/AF & $\wedge, \| \mu$ & $11 / 01$ & $1 \cdot v$ & نيم دهם .q" \\
\hline
\end{tabular}

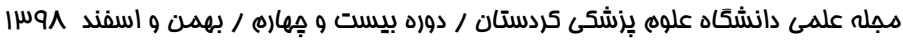


تهران (ه.1 سال) و دكتر فاطمى اردبيل (9V سال) قديمىترين بيمار ستانهاى كشور بودند (جدول9).
حدود ههـ/ بيمارستانهاى كشور بالاى ·r سال قدمت دارند.

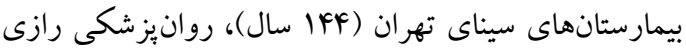

\begin{tabular}{|c|c|c|}
\hline \multicolumn{2}{|c|}{ بيمارستان } & \multirow[t]{2}{*}{ قدمت } \\
\hline درصد & تعداد & \\
\hline$r Y / \Delta \Lambda$ & rl. & كمتر از ·. سال \\
\hline rY/A. & rIr & ا' تا •r سال \\
\hline $10 / \Gamma \Lambda$ & IFT & اץ تا •r سال \\
\hline $9 / \wedge 9$ & $9 r$ & آسا •• سال \\
\hline $10 / \cdot 0$ & If. & أF تا • •ه سال \\
\hline$\Delta / Y V$ & pq & اله تا ·9 سال \\
\hline$r / v 9$ & ro & ا9 تا ·Vسال \\
\hline Y/YG & YI & ال تا •^גسال \\
\hline$r / \cdot F$ & 19 & ای1 تا •9 سال \\
\hline$\cdot / 9 V$ & 9 & بيشتر 11 سال \\
\hline $1 \cdots$ & 94. & كل \\
\hline
\end{tabular}

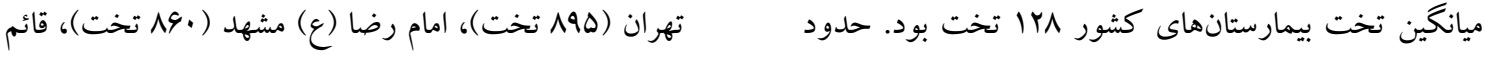

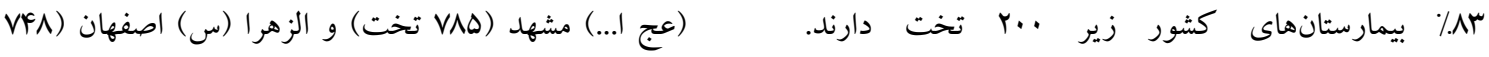

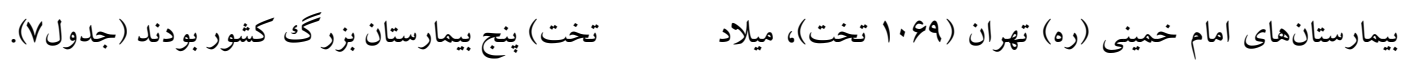
جدولV. ييمارستانهاى كثور به تفكيك تعداد تختهاى فعال

\begin{tabular}{|c|c|c|}
\hline درصد & تعداد بيمارستان & تعداد تخت \\
\hline $\mathrm{KQ/Y \Delta}$ & FOA & كمتر از ..1 \\
\hline m/ve & MIf & $r \cdots-1 \cdots$ \\
\hline $1 \pi / \cdot 1$ & $|r|$ & $\mu_{\cdots}-r_{\cdots}$ \\
\hline$r / \Delta \Lambda$ & YF & $q \ldots-q \ldots$ \\
\hline $1 / \cdot 1$ & 1. & $\Lambda \cdots-9 \cdots$ \\
\hline T/M & $r$ & بالاتر از . ي. \\
\hline $1 \cdots$ & 94. & كل \\
\hline
\end{tabular}

بوده است (نمودار F). نموداره نيز به نوعى نشان مىدهد كه استانهاى ايلام، بوشهر و خراسان جنوبى بيمارستانهاى

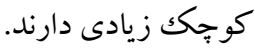

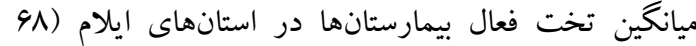
تخت)، بوشهر (V9 تخت) و خراسان جنوبى (19 تخت) بسيار وِايين و در استانهاى قم (IVV) تخت) و جهار محال بختيارى (DF ت تخت) در حد متوسط 


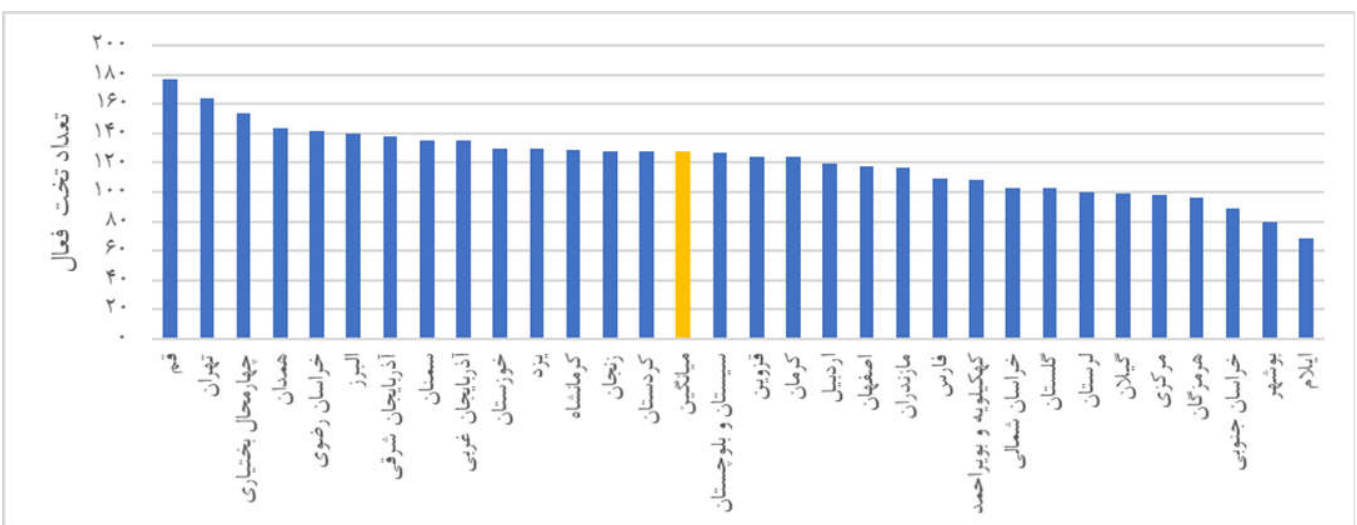

نمودار F. ميانكين تعداد تختهاى فعال بيمارستانى استانهاى ايران در سال هوسا

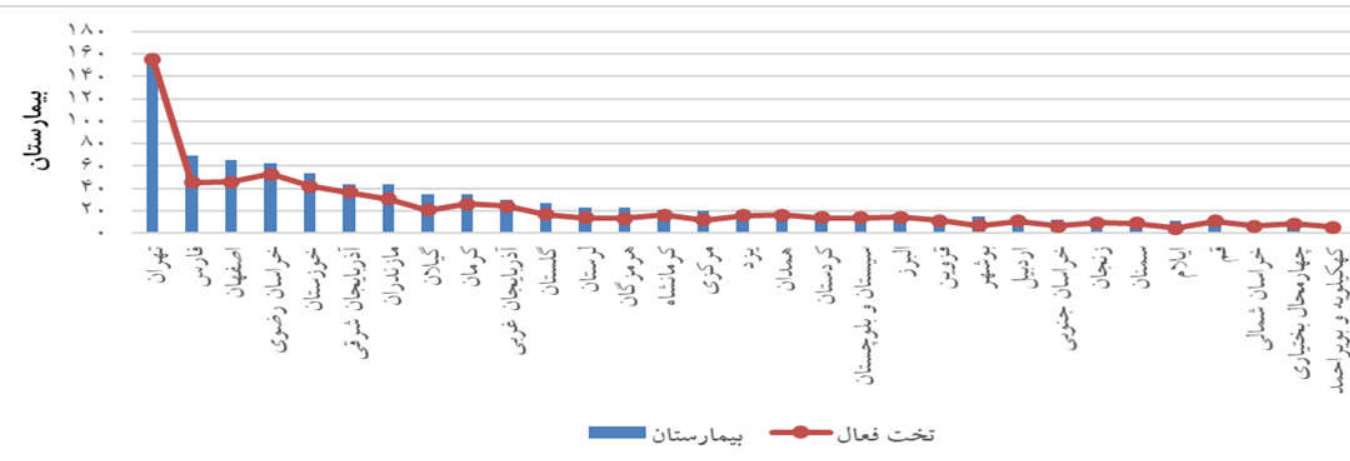

r....

ro...

r.....

,$\ldots$.

o...

نمودارهه ارتباط بين تعداد بيمارستان و تختهاى فعال بيمارستانى استانهاى ايران در سال هوسا

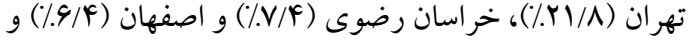
كمترين تعداد تخت بيمارستانى در استانهاى خراسان شمالى (9/4)، كهكيلويه و بويراحمد (V/•٪) و ايلام (19 •\%) وجود داشته است (جدول ^).

جدولى بيمارستانها و تخت هاى فعال بيمارستانى به تفكيك استان
IV) بيشترين تعداد بيمارستانهاى كشور در استانهاى تهران

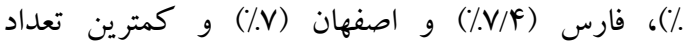
بيمارستانها در استانهاى كهكيلويه و بويراحمد (9/.٪)، جهارمحال بختيارى (1/) و خراسان شمالى (1/1\%) وجود داشته است. بيشترين تعداد تخت بيمارستانى در استانهاى

\begin{tabular}{|c|c|c|c|c|c|c|c|}
\hline \multirow{2}{*}{ تخت به ازاى هزار } & \multicolumn{2}{|c|}{ جمعيت } & \multicolumn{2}{|c|}{ تخت فعال } & \multicolumn{2}{|c|}{ بيمارستان } & \multirow{2}{*}{ استان } \\
\hline & درصد & تعداد & درصد & تعداد & درصد & تعداد & \\
\hline $1 / 9$ & $19 / 9$. & $I r, Y g V, g r V$ & YI/VG & ro, 199 & $19 / 99$ & 101 & ت تهران \\
\hline $1 / 9$ & $9 / \cdot V$ & $F, \wedge \Delta 1, Y V F$ & $9 / \pi F$ & V,DHY & $V / F Y$ & 99 & فارس \\
\hline $1 / 0$ & $9 / 41$ & $\Delta, \mid r \cdot, \Delta \Delta$. & $G / F D$ & $\mathrm{~V}, 9 \mathrm{~V}$. & $9 / 99$ & 90 & اصفهان \\
\hline $1 / 4$ & $\Lambda / \cdot \Delta$ & $\varphi, F r F, \Delta \cdot 1$ & $V / F$. & $\wedge, \wedge \cdot f$ & $9 / 9 \mathrm{~V}$ & $4 Y$ & خر اسان رضوى \\
\hline $1 / 0$ & $\Delta / \wedge q$ & $f, v l \cdot, \Delta \cdot q$ & $\Delta / q$. & $v, \cdot 1 f$ & $\Delta / \Lambda I$ & $\Delta F$ & خوزستان \\
\hline $1 / 9$ & $F / \wedge q$ & $r, 9 \cdot 9,90 r$ & $\Delta / 1$. & 9,91 & $f / N$ & FF & آذربايجان شرقى \\
\hline
\end{tabular}




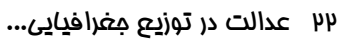

\begin{tabular}{|c|c|c|c|c|c|c|c|}
\hline 1/9 & $F / 11$ & $r, r \wedge r, \Delta \wedge r$ & $F / \mu$ & $\Delta, 1 \pi$. & $\varphi / N^{\mu}$ & FF & مازندران \\
\hline $1 / 4$ & $r / I V$ & $r, \Delta r \cdot, 999$ & $r / 91$ & $r, r \Delta \Lambda$ & r/ve & ro & كيلان \\
\hline $1 / 4$ & r/aq & $r, \mid 94, V \backslash \Lambda$ & $r / 90$ & F, MFY & r/ve & ro & كرمان \\
\hline $1 / r$ & $4 / .9$ & $r, r 90, r 1 q$ & $r / 4$. & $F, \cdot r \lambda$ & r/r & $r$. & آذربايجان غربى \\
\hline $1 / \Delta$ & $r / \mu F$ & $1, \wedge 9 \wedge, \wedge 19$ & T & $r, W V F$ & $r / 9$. & rV & كلستان \\
\hline $1 / \pi$ & $r / Y$. & $1, \mathrm{Vq} \cdot, 949$ & 1/94 & $r, Y q F$ & $r / F V$ & rr & ل ل لرستان \\
\hline $1 / r$ & $r / Y r$ & $1, \mathrm{~V} V \bar{F}, F 10$ & $1 / 19$ & $r, r \cdot q$ & $r / \mathcal{A V}$ & r & هرمز كان \\
\hline $1 / 4$ & $r / F F$ & $1,9 \Delta Y, F \sim F$ & $r / Y \Lambda$ & $r, V \cdot V$ & $r / Y q$ & r & كر مانشاه \\
\hline $1 / 4$ & $1 / 29$ & $1, F Y q, F \vee D$ & $1 / 94$ & 1,999 & $r / 10$ & $r$. & مر كزى \\
\hline$r / r$ & I/FY & س & $r / M \Lambda$ & $r, \Delta Q Y$ & $r / 10$ & $r$. & يزد ل يز \\
\hline $1 / 9$ & $r / I V$ & $1, \mathrm{Vr \Lambda}, \mathrm{r} \mu \mathrm{F}$ & $r / Y q$ & $r, V Y V$ & $r / \cdot r$ & 19 & همدان \\
\hline $1 / 4$ & $r / \cdot 1$ & $1,9 \cdot 4, \cdot 11$ & $1 / 94$ & $r, r \cdot r$ & $1 / 94$ & 11 & كردستان \\
\hline$\cdot / \Lambda$ & $r / \mu V$ & $r, V V \Delta, \cdot \mid r$ & $1 / 9 Y$ & $r, r V \wedge$ & $1 / 94$ & 11 & سيستان و بلو جستان \\
\hline$\cdot / 9$ & $r / r q$ & $r, V \backslash r, Y \cdots$ & $r / \cdot \cdot$ & $r, r \wedge l$ & l/Ar & IV & البرز \\
\hline $1 / \Delta$ & $1 / 09$ & $1, r \vee r, v 91$ & $1 / \Delta V$ & $1, \wedge g F$ & $1 / 91$ & 10 & قزوين \\
\hline $1 / \cdot$ & $1 / 49$ & $1,19 \pi, 4 \ldots$ & $1 / \cdot \cdot$ & 1,119 & $1 / 91$ & 10 & بوشهر \\
\hline $1 / 4$ & $1 / 09$ & $1, Y V \cdot, F Y$. & $1 / 01$ & 1,1991 & $1 / 91$ & 10 & اردبيل \\
\hline $1 / 4$ & $\cdot / 99$ & 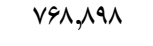 & $\cdot / 19$ & $1, \cdot 94$ & $1 / r 9$ & Ir & خر اسان جنوبى \\
\hline $1 / \Delta$ & $1 / \pi r$ & $1, \cdot \Delta V, \& \& 1$ & $1 / 49$ & $1, \Delta \mathrm{DH}$ & $1 / 79$ & ir & زنجان \\
\hline $1 / r$ & $\cdot / M$ & $V \cdot r, r q$. & $1 / Y \Delta$ & $1, F \wedge \Delta$ & $1 / 11$ & 11 & سمنان \\
\hline $1 / \pi$ & $\cdot N^{r}$ & $\Delta \Lambda \cdot, \mid \Delta \Lambda$ & $.19 \pi$ & $V F a$ & $1 / 1 \Lambda$ & 11 & ايلام \\
\hline $1 / 4$ & $1 / 94$ & I, YQY, YAr & $1 / 49$ & $1, \mathrm{~V} r$ & $1 / \cdot 1$ & 1. & قم \\
\hline $1 / T$ & $1 / \cdot 1$ & NGT, $\cdot 9 r$ & $\cdot / A V$ & $1, \cdot r$. & $1 / \cdot 1$ & 1. & خر اسان شمالى \\
\hline $1 / \Delta$ & $1 / 19$ & AFV,VAT & $1 / / V$ & $1, r \wedge 9$ & $\cdot / 9 V$ & 9 & جهارمحال بختيارى \\
\hline $1 / r$ & $\cdot / \wedge 9$ & VIr, $\cdot \Delta r$ & $\cdot / N$ & NG4 & $\cdot / 19$ & $\wedge$ & كهكيلويه و بوير احمد \\
\hline $1 / 0$ & $1 \cdots$ & vq,qrq, rv. & $1 \cdots$ & $111 \wedge, \wedge 94$ & $1 \cdots$ & 94. & جمع كل \\
\hline
\end{tabular}

(190/•) و قم (/VV) كمترين بيمارستان را به ازاى هر صد

هزار نفر جمعيت داشتند. نمودارV نيز به نوعى نشان مىدهد

كه استانهاى البرز، سيستان و بلوجستان، قم، خراسان رضوى و آذربايجان غربى نسبت به ميانگين كشور با كمبود بيمارستان مواجه هستند.
جمعيت كشور در سال هوب| برابر با · V9,9Y9, نفر بود؛ بنابراين، تعداد 1/19 بيمارستان به ازاى هر صد هزار نفر جمعيت در ايران در اين سال وجود داشت (نمودار4). استانهاى ايلام (1/9)، يزد (I/V9) و سمنان (I/DV ) بيشترين بيمارستانها و استانهاى البرز (سو/•)، سيستان و بلوجستان 


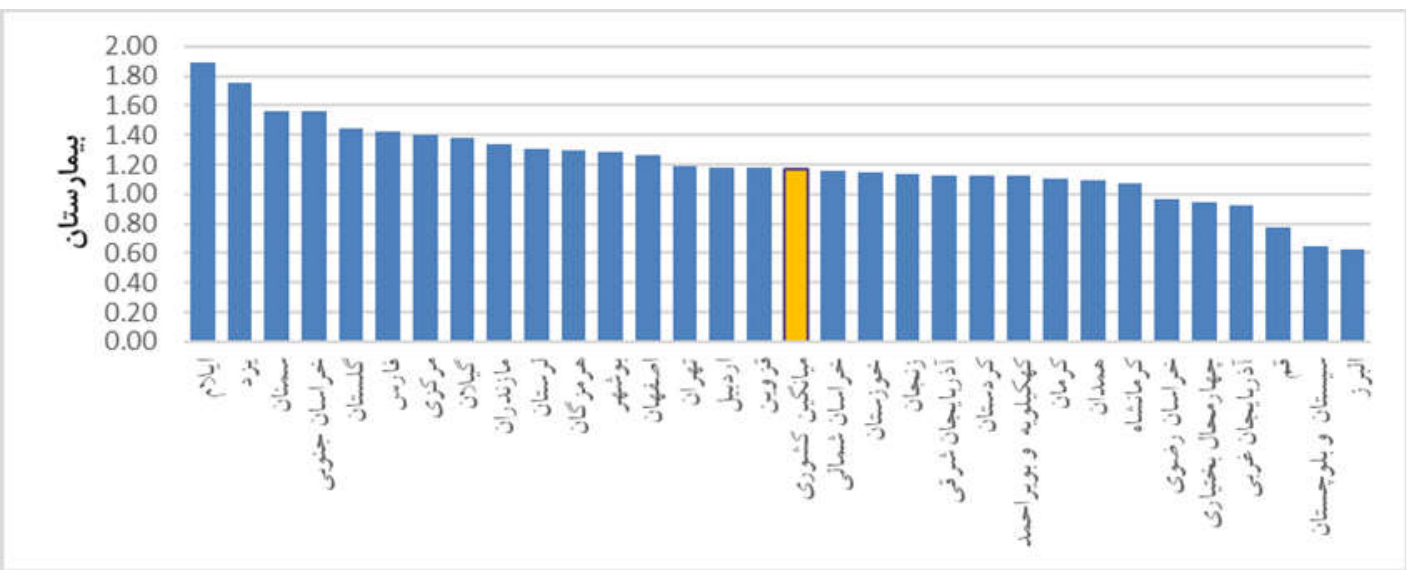

نمودار 9. تعداد بيمارستان به ازاى صد هزار نفر جمعيت به تفكيك استانهاى كشور در سال هوسا

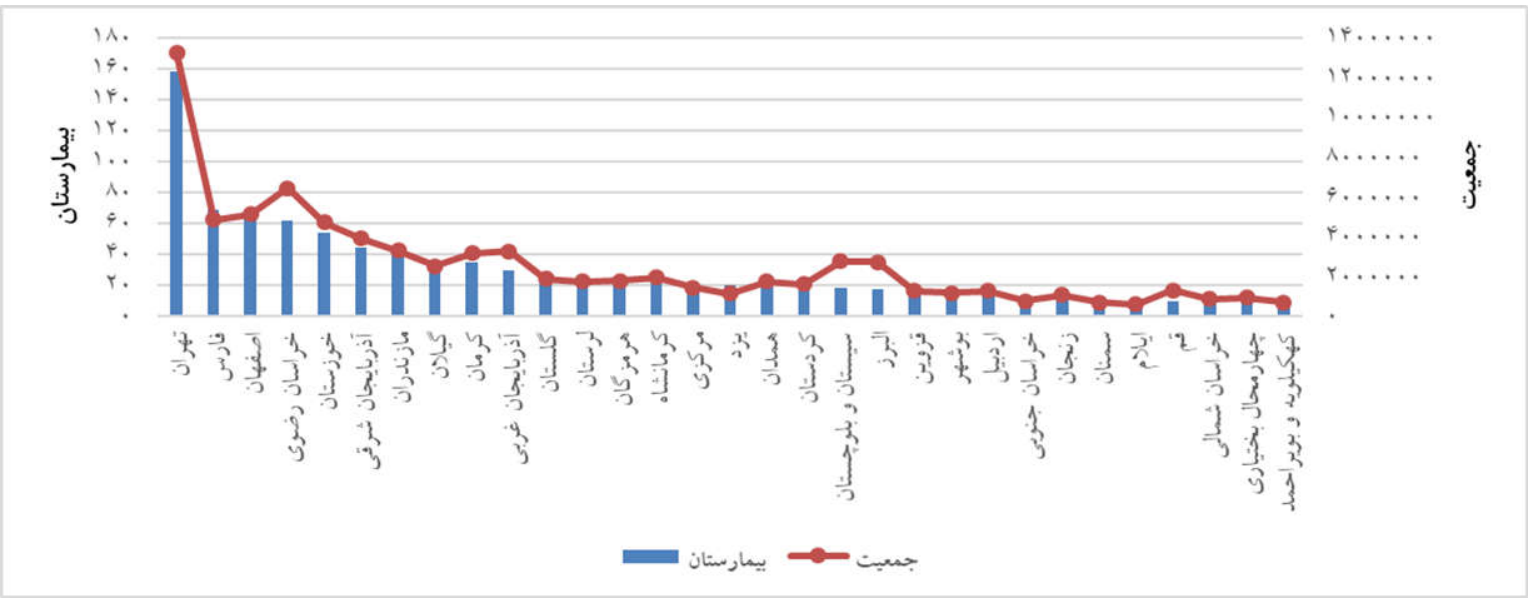

نمودار V. ارتباط بين جمعيت و تعداد بيمارستانهاى كشور در سال هوسا

ازاى هزار نفر جمعيت به ترتيب مربوط به استانهاى سيستان و بلوحستان (^/•)، البرز (9/•)و بوشهر (•/1) بود. نمودار 9

تعداد جمعيت و تختهاى بيمارستانى كشور ايران به تفكيك استانها را در سال هوسا نشان مىدهد.
تعداد ه/ آخت به ازاى هر هزار نفر جمعيت در ايران در سال هوسا وجود داشت (نمودار ^). بيشترين تعداد تخت به ازاى هزار نفر جمعيت به ترتيب مربوط به استانهاى يزد (Y/Y) 


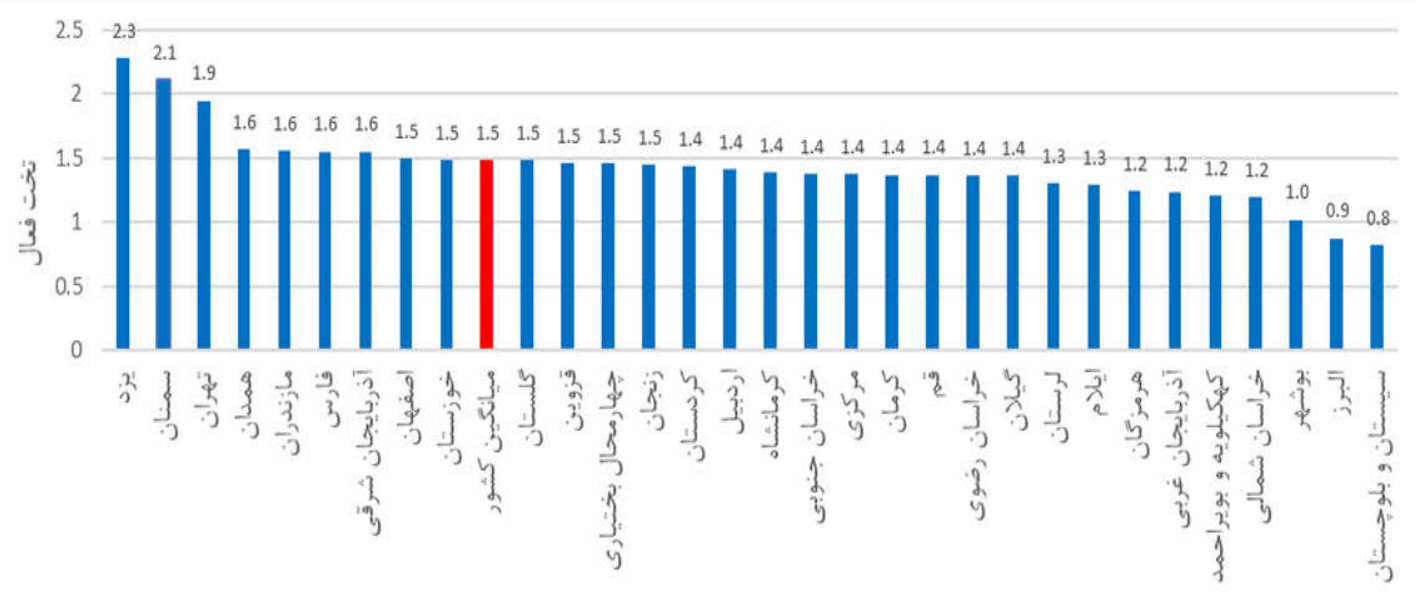

نموداری. تعداد تخت به ازاى هزار نفر جمعيت به تفكيك استانها در سال هه؟|

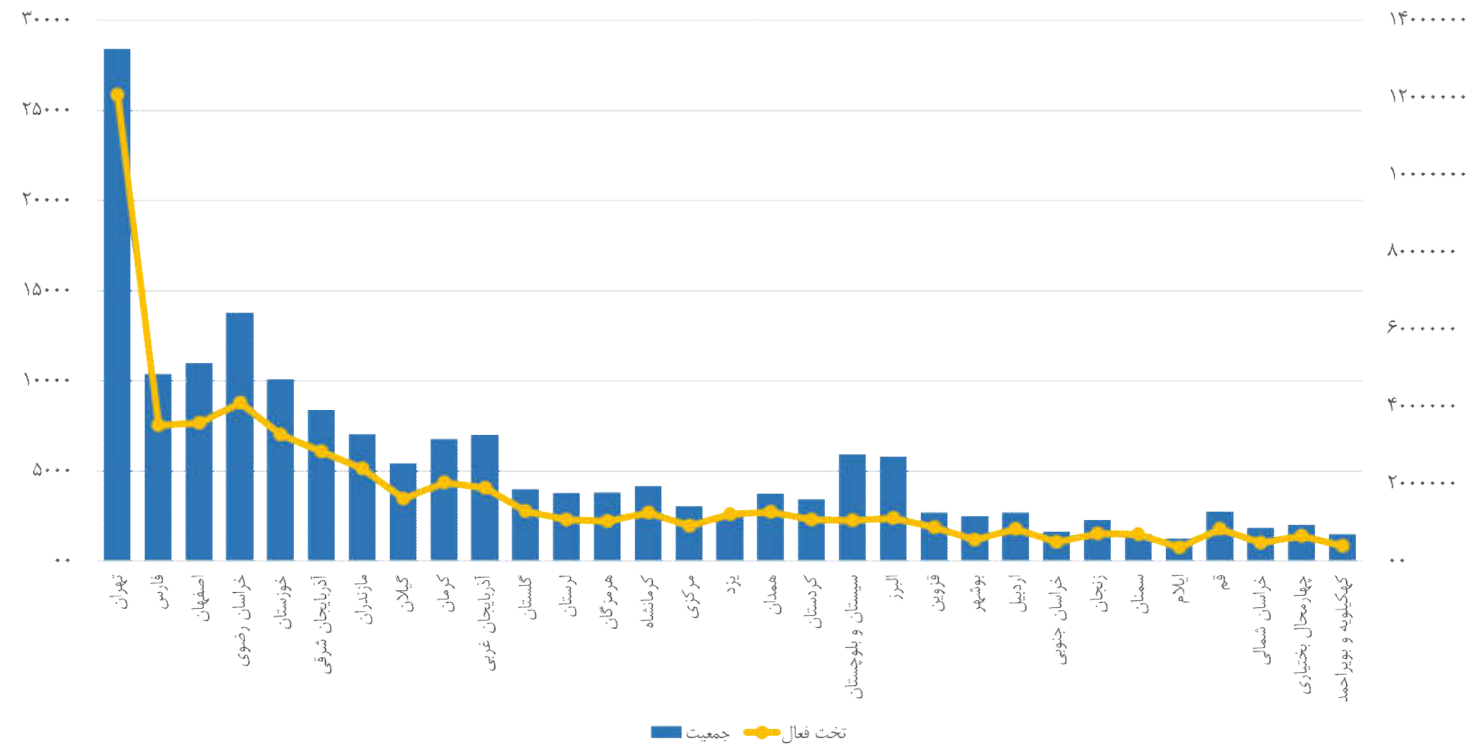

نمو داره. ارتباط بين تعداد جمعيت و تختهاى بيمارستانى استانهاى ايران در سال هوس|

كرمانشاه، خراسان جنوبى، مركزى، كرمان، قم، خراسان رضوى، گيلان، لرستان، ايلام، هرمز گان، آذربايجان غربى،

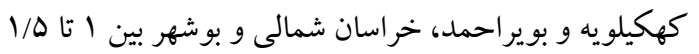
تخت و استانهاى سمنان و يزد بيشتر از r تخت به هر هزار نفر جمعيت داشتند (شكل ().
بيشتر استانهاى كشور بين ا تا ه/ا تخت به ازاى هر هزار نفر جمعيت در سال هوبا داشتند (Y استان). بيشتر تعداد تختهاى بيمارستانى در مركز ايران و نزديك به استان تهران بوده است. استانهاى اصفهان، خوزستان، كلستان، قزوين، جهارمحال بختيارى، زنجان، كردستان، اردبيل، 


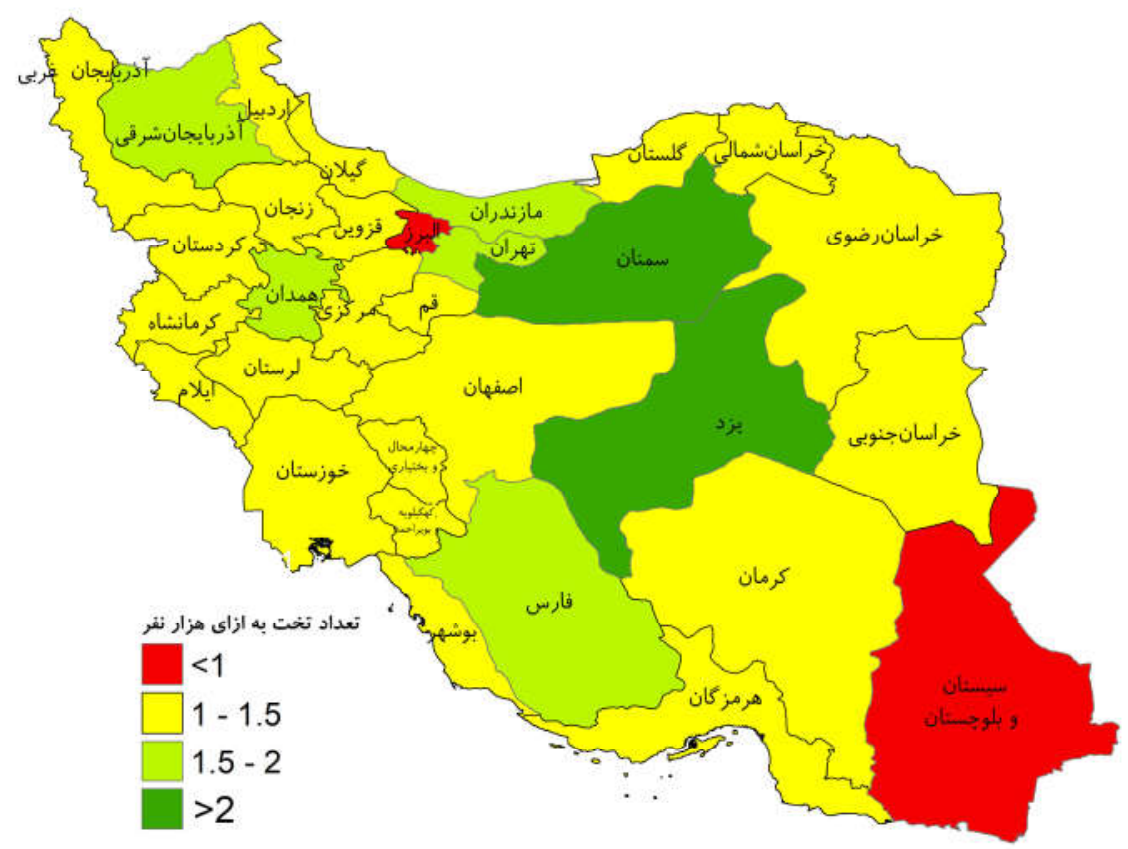

شكل ا. توزيع تخت به ازاى هزار نفر جمعيت در استانهاى ايران در سال هوسا

كمترين تعداد تخت به ازاى هزار نفر جمعيت را داشتند. تعداد WV شهرستان بيش از ه/ إخت به ازاى هزار نفر

$$
\text { جمعيت داشتند (نمودار ·(1). }
$$

تعداد qYq شهرستان در سال هوץ| در ايران وجود داشت.

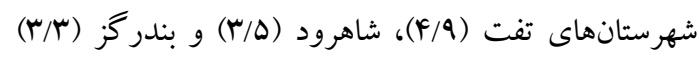
بيشترين تعداد تخت به ازاى هزار نفر جمعيت را داشت. در مقابل، شهرستانهاى ملارد، فرديس، قرجّك و پِرديس،

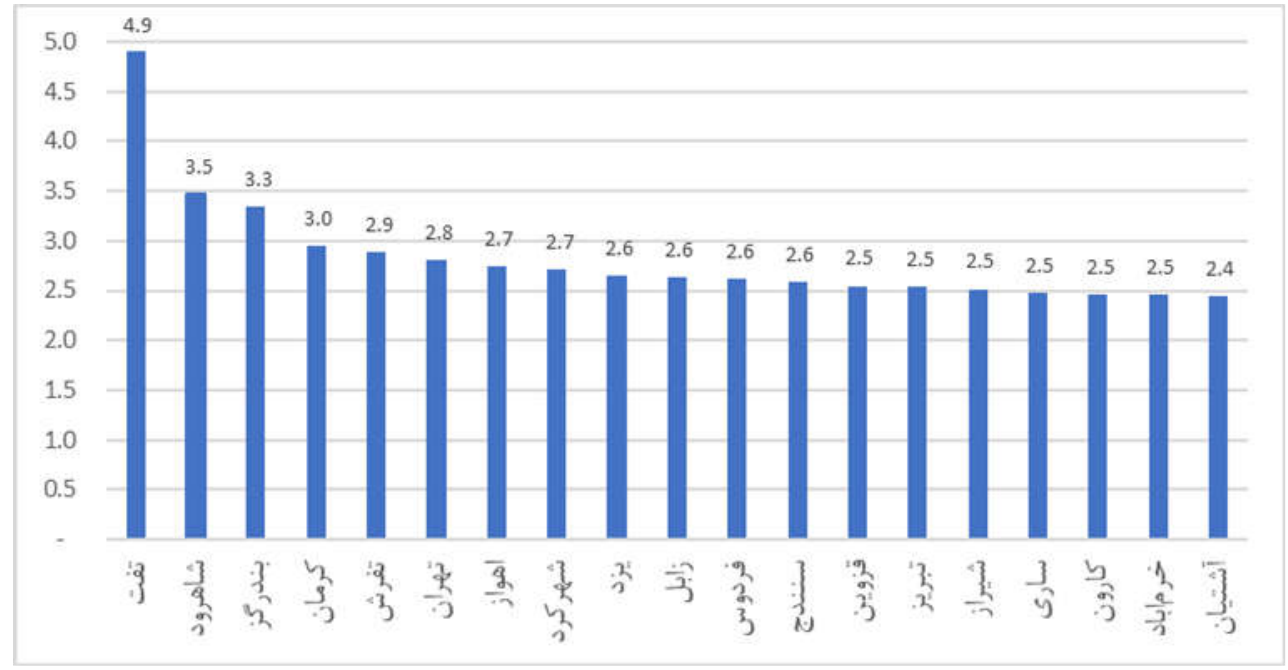

نمودار · ا. شاخص تخت به ازاى هزار نفر جمعيت به تفكيك شهرستانها در سال هوب1 
(

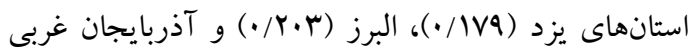
( ) كمترين مقدار ضريب جينى توزيع تخت فعال بيمارستانى را دارا بودند (نمودار Y ا و شكل Y).
ميزان ضريب جينى براى توزيع تختهاى بيمارستانى در

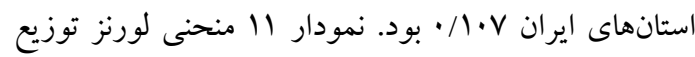
تختهاى بيمارستانى ايران را در سال هوسا نشان مىدهد. استانهاى خراسان شمالى (19.9•)، سيستان و بلوجستان

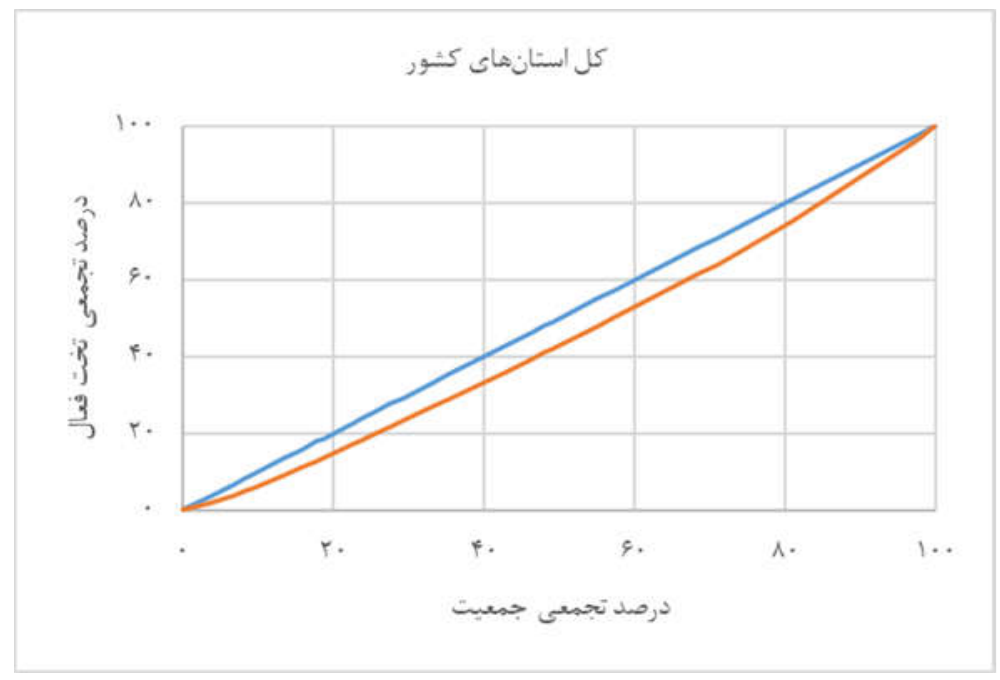

نمودار 11. منحنى لورنز توزيع تختهاى بيمارستانى ايران نسبت به جمعيت استانهاى كشور در سال هوس|

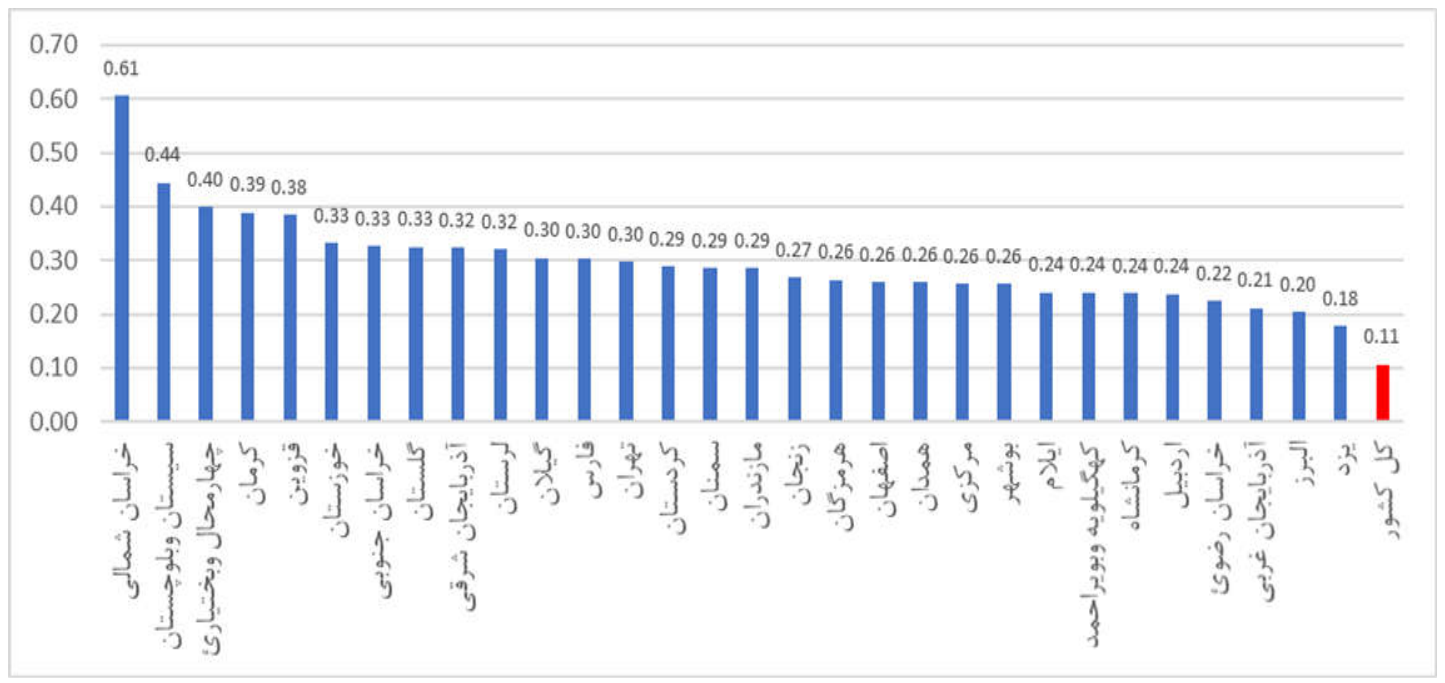

نمودار | ا. ضريب جينى توزيع تخت فعال بيمارستانى در استانهاى كشور ايران در سال هوس| 


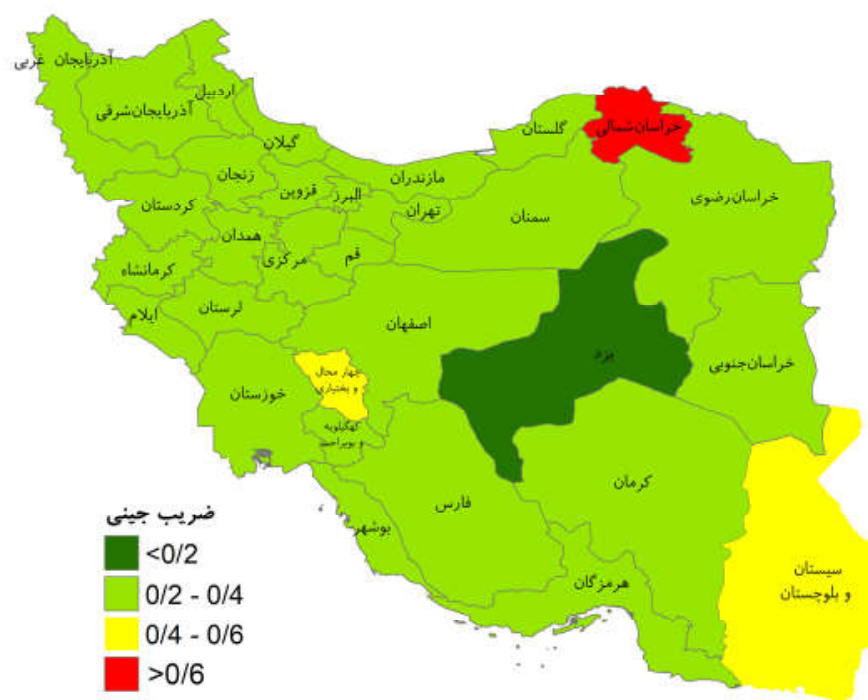

شكل r. ضريب جينى توزيع تخت فعال بيمارستانى در استانهاى كشور ايران در سال هوس|

(IVq) ناعادلانهترين توزيع تختهاى بيمارستانى در استانهاى خراسان شمالى (9.9/•)، سيستان و بلوجستان (FFD/•) و جهارمحال و بختيارى ( • • • •) است (نمودارس|).

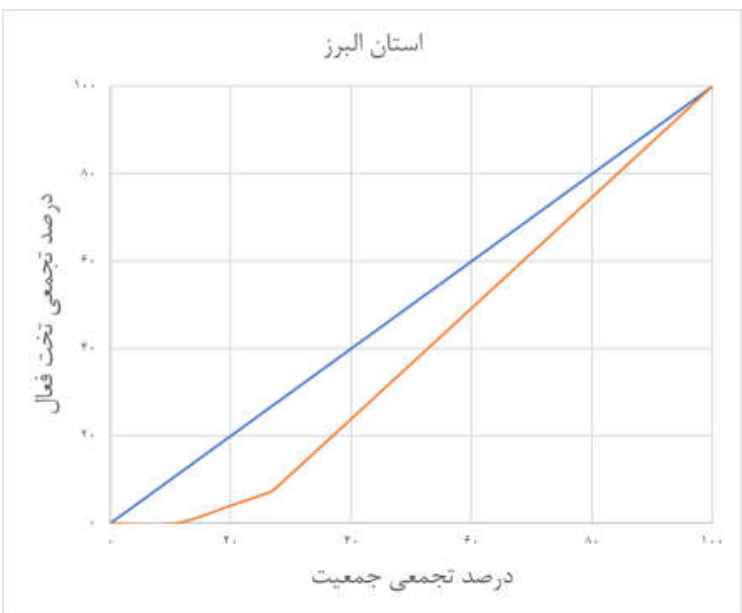

همجنين، منحنى لورنز براى توزيع تختهاى بيمارستانى در شهرستانهاى هر استان با استفاده از درصد تجمعى جمعيت و تخت هر شهرستان محاسبه شد. عادلانهترين توزيع تختهاى بيمارستانى در بين شهرستانها در استانهاى يزد

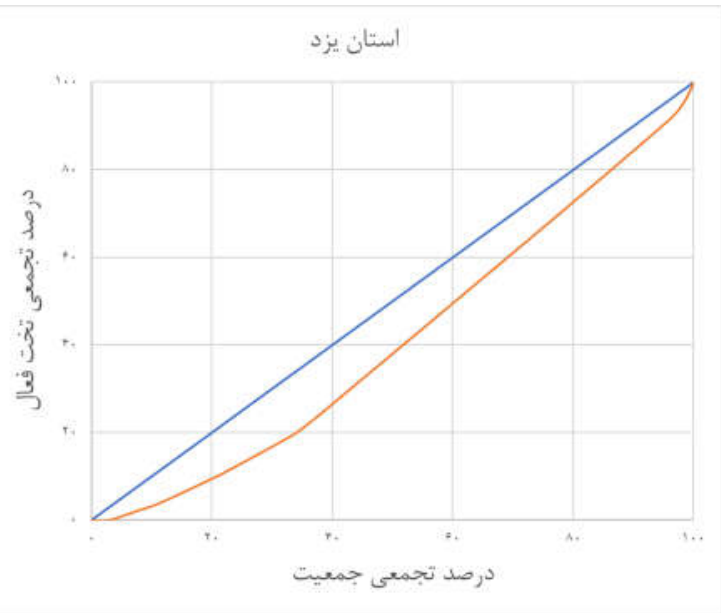




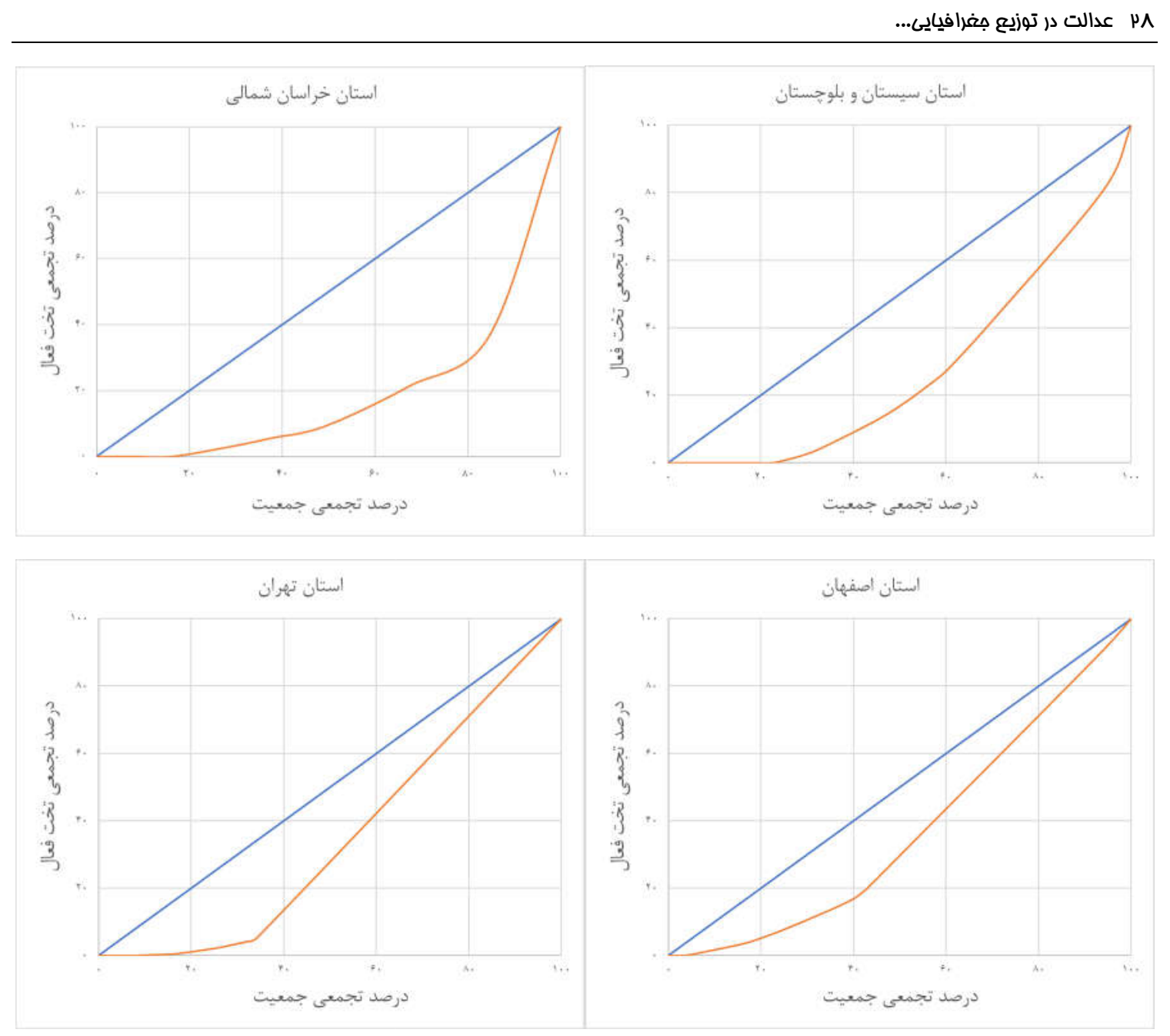

نمودار سا. منحنى لورنز توزيع تختهاى بيمارستانى برخى از استانها نسبت به جمعيت شهرستانهاى استان در سال هوس|

اين شاخص در منطقه مديترانه شرقى كه ايران هم جزو آن بحث

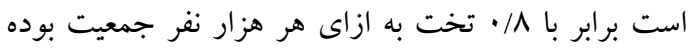

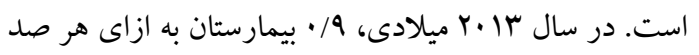
هزار نفر جمعيت در منطقه مديترانه شرقى وجود داشت (ه).

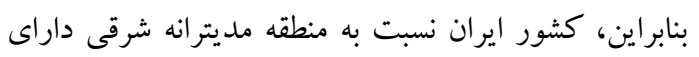
وضعيت مطلوبى است. با اين وجود، اين شاخص به منظور

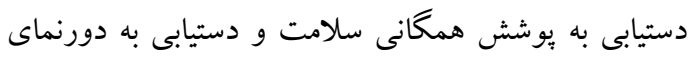

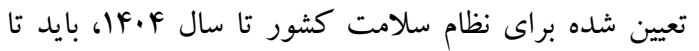

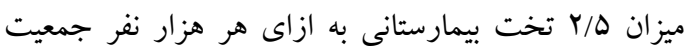

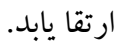

اين بزوهش با هدف بررسى عدالت در توزيع جغرافيايى

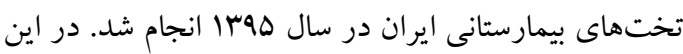

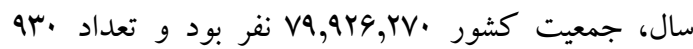

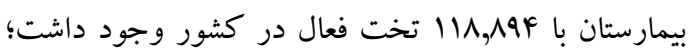
بنابراين، تعداد آ بيمارستان به ازاى هر صد هزار نفر

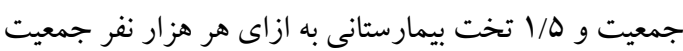

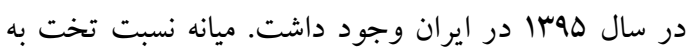

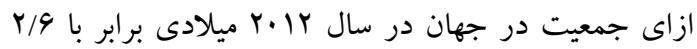

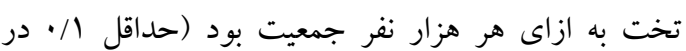
كشور مالى و حداكثر //rا تخت در كشور موناكو) بود. 
فرديس، قرجك و يرديس كمترين تعلاد تخت به ازاى جمعيت را داشتند. كمبود تختهاى بيمارستانى منجر به كاهش استفاده از خدمات بيمارستانى و همجينين، اعزام بيماران به ساير شهرهاى بزرك به ويزه مراكز استانها مىشود كه در نهايت، علاوه بر نارضايتى بيماران منجر به افزايش هزينهاى نظام سلامت خواهد شد. در مقابل، افزايش بىرويه تختهاى بيمارستانى در يكك جمعيت بيمهده بر اساس قانون رومر، منجر به افزايش ميزان يذيرشهاى بسترى بيماران خواهد شد. آقاى ميلتون رومر يُزوهشخر آمريكايى معتقد بود كه به دليل تقاضاى القايى از بـاز ناحيه ارائه كننده خدمات سلامت، يكك تخت ساخته شده در يك جمعيت بيمه شده، يك تخت ير شده محسوب

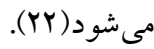
بيشتر بيمارستانهاى كشور از نوع عمومى هستند (حدود م4

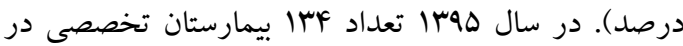

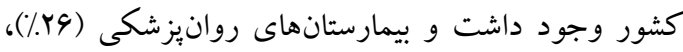
زنان و زايمان (ها؟) و اطفال (rا/\%) هم بيشترين بيمارستانهاى تخصصى كشور را تشكيل دادند. ساخت بيمارستانهاى تكك تخصصى اگرجهه با مزايايى همراه است، وليكن، بيمارستانهاى تكك تخصصى با توجه به نياز بيماران

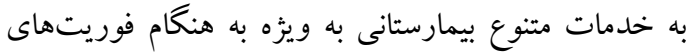

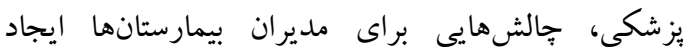

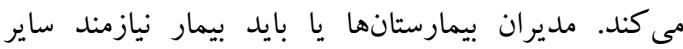

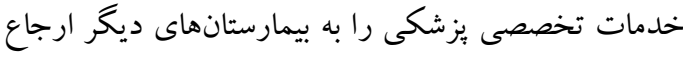

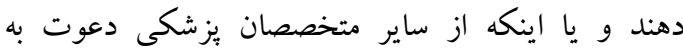
همكارى كنند و تسهيلات و تجهيزات مربوطه راخريدارى كنند كه هزينه زيادى به بيمارستان تحميل مى كند. با اين وجود، تفاوت در بار بيمارىها بايد در تخصيص تختهاى

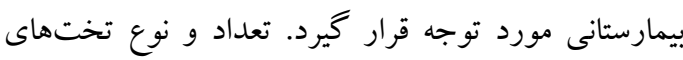
بيمارستانى بايد با توجه به نوع نياز مردم منطقه تعيين شود

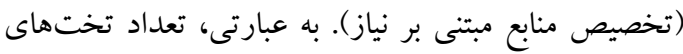
كروههاى تخصصى در بيمارستانهاى عمومى كشور بايد
دهاهاى ·V، •1ی و ·9 شمسى شاهد جهشى در امر بيمارستان سازى در ايران بوديم. در اين دههها توليد ناخالص داخلى ايران افزايش جشمخيرى داشته است. دولت با اتخاذ سياستهاى مالى و يولى مناسب انبساطى و انقباضى، در زمانهاى ركود و رونق اقتصادى، بايد نياز كشور به تختهاى بيمارستانى را مديريت كند. سازمانهاى متعددى نظير دانشكاههاى علوم يزشكى، تأمين اجتماعى، نيروهاى

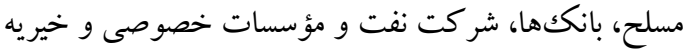
در ايران داراى بيمارستان هستند. از طرف ديخر، بيمههاى يايه درمان كه نقش بسزايى در تأمين مالى بيمارستانها

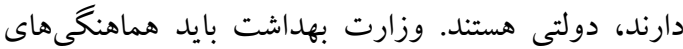
لازم را بين اين سازمانها در ساخت و توسعه بيمارستانها به

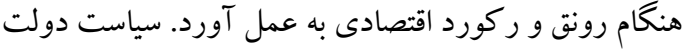
در زمان رونق اقتصادى بايد تشويق بخش خصوصى به ساخت و توسعه بيمارستانها باشد و در زمان ركود اقتصادى، خود به مديريت تختهاى بيمارستانى موجود و در صورت نياز ساخت بيمارستانها بيردازد. عدم توجه به اين اصل مهم منجر مىشود كه در زمان رونق اقتصادى با افزايش بيش از اندازه تختهاى بيمارستانى و در زمان ركود اقتصادى با كمبود تختهاى بيمارستانى مواجه شويم. استانهاى ايلام، يزد، سمنان، خراسان جنوبى و كلستان بيشترين بيمارستانها و استانهاى البرز، سيستان و بلوجستان، قم، خراسان رضوى و آذربايجان غربى كمترين بيمارستان را

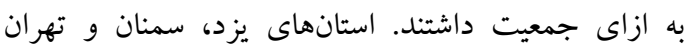
بيشترين و استانهاى سيستان و بلوجستان، البرز و بوشهر كمترين تعداد تخت به ازاى جمعيت را داشتند. استان تهران

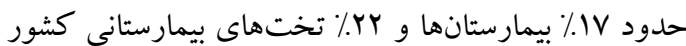
را به خود اختصاص داده، درحالى كه 19/9٪ جمعيت كشور

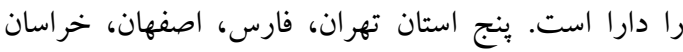
رضوى و خوزستان حدود نيمى (FN//\%) از بيمارستانهاى كشور را دارا هستند. شهرستانهاى تفت، شاهرود و بندر گز بيترين تعداد تخت به ازاى جمعيت و شهر ستانهاى ملارد، 
شهرستانها با توجه به شرايط اجتماعى و اقتصادى فعلى جامعه بيشنهاد مىشود.

ميزان كارايى بيمارستانهاى ايران در حد متوسط است

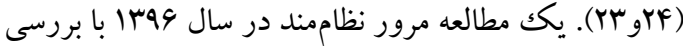
ا 9 مقاله يُزوهشى، كارايى بيمارستانهاى ايران رادر دو دهه

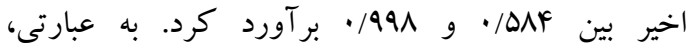
بيمارستانهاى كشور از كارايى لازم برخوردار نبودند(M). مطالعه مرور نظاممند ديخرى در سال Vوrا با بررسى 194 مقاله ئزوهشى اصيل به ارزشيابى عملكرد بيمارستانهاى ايران در دو دهه اخير يرداخت. كارايى بيمارستانها در بيشتر مطالعات كم تا متوسط كزارش شده بود(YF)؛ بنابراين، سياست گذاران و مديران ارشد نظام سلامت بايد در زمينه نحوه تخصيص صحيح منابع محدود به نيازهاى نامحدود مردم تصميم بكيرند. استفاده كارآمد از منابع محدود موجود، براى باسخكويى به نيازهاى نامحدود مردم بايد مورد توجه سياست گذاران و مديران قرار گيرد.

كارايى به طور كلى، به دو دسته كارايى تخصيصى و كارايى فنى تقسيم مى شود. كارايى تخصيصى شامل هدايت منابع به سوى مصارفى با بيشترين تقاضا و مطلوبيت است(ب (Y). سياست گذاران نظام سلامت بايد عدالت عمودى را در تخصيص تختهاى بيمارستانى مورد توجه قرار دهند. بار بيمارىها در استانها و شهرهاى ايران متفاوت است؛ بنابراين، براى افزايش كارايى تخصيصى بيمارستانها، بايد تعداد و نوع تختهاى بيمارستانى متناسب با نياز مردم جامعه

باشد.

علاوه بر اين، تصميم گيرى در زمينه تعداد تخت مطلوب يكك بيمارستان بايد بر پايه محاسبات اقتصادى صورت گيرد.

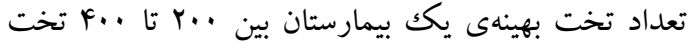
است. در اين حالت از تخصص هاى مختلف و تجهيزات كران قيمت بيمارستان استفادهى بهينه خواهد شد(ب(Y). اين يُزوهش نشان داد كه ميانگين تخت بيمارستانهاى كشور در

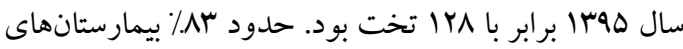

متناسب با نيازهاى مردم منطقه تحت يوشش بيمارستان تعيين

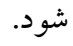

حدود يك جهارم (4/9 (Y/) بيمارستانهاى كشور آموزشى درمانى هستند. اين بيمارستانها حدود ه \&\% تختهاى بيمارستانى كشور را به خود اختصاص دادند. با توجه به اينكه اكثريت بيمارستانهاى آموزشى درمانى در زمره بيمارستانهاى دانشخاهى دولتى قرار مى گيرند، مىتوان كفت كه به ترتيب حدود بو٪ بيمارستانهاى دانشگاهى دولتى و 99٪ تخت هاى بيمارستانهاى دانشگاهى از نوع آموزشى و درمانى هستند. مراجعه مردم به ويثه اقشار كمدر آمد جامعه به بيمارستانهاى دانشگاهى دولتى با توجه به تعرفه يايين آنها زياد است؛ بنابراين، نسبت بيمارستانهاى آموزشى درمانى از كل بيمارستانهاى دانشگاهى دولتى بايد به گونهاى باشد كه مردم به اندازه كافى، امكان انتخاب بيمارستانهاى دانشگاهى دولتى غير آموزشى را هم داشته باشند.

اين يُزوهش نشان داد كه توزيع تختهاى بيمارستانى در استانهاى كشور عادلانه (ضريب جينى ||/×) بوده، ولى در شهرستانهاى استانهاى كشور تا حدودى ناعادلانه بوده است. تختهاى بيمارستانى در استانهاى يزد، البرز و آذربايجان غربى بهطور عادلانه و در استانهاى خراسان شمالى، سيستان و بلوجّتان و جهارمحال و بختيارى بهصورت ناعادلانه توزيع شدند. بيشتر بيمارستانها و تختهاى بيمارستانى در مراكز استانها تجمع يافتند. توزيع ناعادلانه منابع منجر به ارجاع بيماران به استانها و شهرستانهاى برخوردار خواهد شد كه هزينه بيشترى به بيماران و در نهايت، نظام سلامت تحميل خواهد كرد و باعث كاهش رضايت و كيفيت زندگى بيماران خواهد شد. ارتقاى كارايى بيمارستانها براى استفاده بهينه از تختهاى موجود بيمارستانى و جلب مشاركت بخش خصوصى و خيريه براى ساخت و تجهيز بيمارستانهاى جديد براى بهبود . عدالت در توزيع بيمارستانها و تختهاى بيمارستانى در 
توانمندسازى مديران و كاركنان بيمارستانها، شناسايى و كاهش اتلاف منابع در بيمارستانها، ارزيابى اقتصادى عملكرد بيمارستانها و ارائه بازخورد به مديران و اجراى استراتزىهاى مديريت كيفيت و مديريت مشاركتى از مهم ترين راهكارهاى افزايش كارايى بيمارستانهاى هستند(9 (-

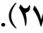

در سال هوبا، ميانگين ضريب اشغال تخت بيمارستانهاى كشور \% \% و و ميانگين متوسط اقامت بيماران در بيمارستانها ه/ب روز بوده است. در نتيجه، ميانگين گردش تخت بيمارستانهاى كشور 91 بار در سال بوده است. ميزان مطلوب ضريب اشغال تخت يكك بيمارستان برابر با ئر درصد است. به عبارتى، از حدود MF هزار تخت بيمارستانى كشور به درستى استفاده نمىشود؛ بنابراين، بدون افزايش تختهاى بيمارستانى كه هزينهزا است، با افزايش كارايى فنى و با هزينه كمتر مىتوان به نيازهاى مردم جامعه ياسخ داد. همجنين، ضريب اشغال تخت بخشهاى مختلف بيمارستانهاى كشور متفاوت است. برخى از بخشهاى يك بيمارستان با مراجعه زياد بيماران مواجه هستند و به دليل كمبود تخت از يذيرش بيماران اجتناب مىشود. در مقابل، بخشهاى ديخر بيمارستان، ضريب اشغال تخت بسيار پايينى دارند و به نوعى ضرر ده محسوب مىشوند. مديران بيمارستانها بايد با استفاده از اطلاعات بيماردهى جامعه به مديريت صحيح تختهاى بيمارستان در سطح خرد اقدام كنند. كاهش متوسط اقامت بيماران در بيمارستان نيز منجر به آزاد شدن ظرفيت تخت بيمارستانى مىشود. همجِنين، مديران بايد به هزينها و در آمدهاى تخت هاى بخشهاى بيمارستانى توجه داشته باشند. روشهاى تحليل آمارى، تئورى صف و شبيه سازى براى محاسبه تعداد بهينه تختهاى هر بخش بيمارستان لطفا مورد استفاده قرار كيرد.

در استانهاى خراسان شمالى، سيستان وبلوجستان، جهارمحال و بختيارى، كرمان و قزوين كه با كمبود تخت به ازاى جمعيت نسبت به ميانگين كشورى مواجه هستند، در

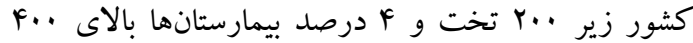
تخت دارند. به عبارتى، فقط ساء بيمارستانها با ظرفيت كار آمد ساخته شدند. در صورتى كه بيمارستانى از كارايى تخصيصى يايينى برخوردار باشد، توانايى مدير براى افزايش كارايى بيمارستان از طريق كارايى فنى، كاهش مىيابد. استانهاى ايلام، بوشهر، خراسان جنوبى، فارس، اصفهان و كَالان بيمارستانهاى كوجّك زيادى دارند. بيمارستانهاى مجهزى در برخى از شهرهاى كوجٍك و محروم كشور ساخته شده است، وليكن، متخصصان علوم يزشكى لازم و كافى براى ارائه خدمات تخصصى در اين بيمارستانها وجود ندارد. در نتيجه، كارايى اين نوع بيمارستانها كم خواهد شد(Y) Yوه). ساخت و تجهيز بيمارستانهاى بسيار

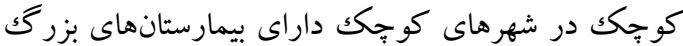
مجهز، توأم با كارايى نيست. دانشگاههاى علوم بزشكى و خدمات بهداشتى درمانى بايد نقش فعالترى در مديريت تختهاى بيمارستانى جامعه تحت يوشش خود ايفا كنند. ادغام بخشهاى بالينى با درصد اشغال تخت پايين جند بيمارستان، راه كار مناسبى براى استفادهى بهينه از منابع بيمارستانى مو جود خواهد بود. در مقابل، كارايى فنى توانايى مدير بيمارستان در به دست آوردن حداكثر ستاده با استفاده از مقدار معين نهادهها، يا استفاده از حداقل نهادهها براى دستيابى به ميزان معين ستادهها است. براى افزايش كارايى فنى مىتوان از روش هاى كارايى مقياسى و كارايى مديريتى استفاده كرد. كارايى مقياسى، كاهش هزينهى متوسط خدمت با افزايش ظرفيت توليد و كارايى مديريتى ناشى از تدبير مديران در تركيب صحيح نهادهاى توليد و استفادهى درست از منابع براى توليد خدمات به صورت كارآمد است(سץ). جلو گيرى از توسعه غير ضرورى بيمارستانها، توزيع صحيح تختها بين بيمارستانهاى شهر، تخصيص تختهاى بيمارستانى متناسب با نياز جامعه، هدايت منابع به خدمات سلامت ير تقاضا، تغيير تعرفه تهاى وبزشى به كلوبال، آموزش و 
منجر به كاهش بذيرش بيماران در بيمارستان مىشود. ارائه مراقبتهاى برستارى در خانه براى بيمارانى كه نياز به خدمات تخصصى يزشكان و خدمات تشخيصى ندارند، يا استفاده از خدمات خانههاى يرستارى براى بيمارانى كه به دلايلى امكان مراقبت در منزل براى آنها يا خانواده آنها وجود ندارد، از اشغال غيرضرورى تختهاى بيمارستانى

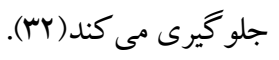

رقابت بين بيمارستانها منجر به بهبود كيفيت و افزايش كارايى فنى آنها مىشود. وزارت بهداشت و دانشگاههاى علوم يزشكى با رعايت كارايى تخصيصى در سطحبندى خدمات بيمارستانى، انجام ارزشيابىهاى اقتصادى هزينهمنفعت و هزينه -اثربخشى براى دادن مجوز ساخت بيمارستان و خريد تجهيزات بيشرفته تشخيصى و درمانى، آموزش مديران و كاركنان بيمارستانها و نظارت بيشتر بر عملكرد بيمارستانها نقش بسزيى در ايجاد رقابت درست بين بيمارستانها دارند. حدود نيمى از بيمارستانهاى كشور

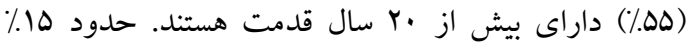
بيمارستانها نيز بالاى .ه سال قدمت دارند. قدمت بيمارستانها منجر به افزايش هزينهها، كاهش كارايى و افزايش نارضايتى كار كنان و بيماران مىشود. با توجه به نوع مالكيت و اندازه بيمارستان بايد در اين زمينه تصميم كرفت. يشنهاد مىشود كه تعداد تختهاى بيمارستانهاى قديمى سيار بزرگك را به حداكثر ·F ت تخت كاهش داد تا منجر به كاهش هزينها و افزايش كارايى اين بيمارستانها شود. شبكهازى و ادغام بيمارستانهاى بسيار قديمى كو جـك نيز راهكار ديخرى براى افزايش كارايى بيمارستانها است. دولت نقش بر رنكى در ارائه خدمات سلامت ايران دارد و با جالشهايى نظير كمبود منابع مالى و نيروى انسانى سلامت مواجه است كه منجر به افزايش هزينه توليد و كاهش كيفيت خدمات سلامت شده است. ارائه خدمات سلامت هزينه -اثربخش نيازمند مشاركت بخش هاى عمومى و خصوصى جامعه است(سM). بخش خصوصى حضور كمترى
درجه اول بايد به افزايش كارايى اين بيمارستانها توجه نمود و از تختهاى موجود بيمارستانى استفاده بهينه شود. ميانخين ضريب اشغال تخت بيمارستانهاى اين ينج استان به ترتيب برابر با 9/4Vا هوسا بوده است(1))؛ بنابراين، امكان ارتقاى كارايى اين بيمارستانها وجود دارد. راهكار بعدى افزايش تعداد تخت بيمارستانهاى با كمتر از ب. r تخت است تا ضمن ياسخگگ ياسيى به نيازهاى مردم جامعه، از منابع بيمارستانها به صورت بهينه استفاده شود و كارايى بيمارستان هم افزايش يابد (صرفهجويى ناشى از افزايش ظرفيت توليد). در نهايت، در صورت نياز مردم جامعه و تكميل بودن ظرفيت

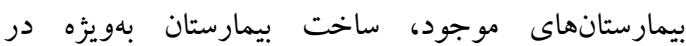
شهرستانهاى محروم استانها با مشاركت بخش خصوصى مورد توجه قرار گيرد.

بازار سلامت با نارسايىهاى متعددى مواجه است كه با قوانين محض اقتصادى عرضه و تقاضا قابل كنترل نيست؛ بنابراين، مداخله و كنترل محدود دولت ضرورى است تا مانع از توسعه غير ضرورى بيمارستانها و به تبع آن افزايش هزينههاى نظام سلامت شود. بايد به اين نكته توجه داشت كه يِيشيرى بر درمان مقدم است. دانشخاههاى علوم يزشكى و خدمات بهداشتى درمانى به عنوان متولى نظام سلامت در سطح استانهاى كشور بايد بر ارائه خدمات يكֶارجه سلامت تأكيد داشته باشند. خدمات بيشخيرى، درمانى و بازتوانى بايد به صورت هدفمند و هماهنگك ارائه شود تا منجر به افزايش اثربخشى و كارايى نظام سلامت شود. تأكيد همزمان بر ارائه خدمات يِيشيرى و بازتوانى اثربخش، منجر به كاهش نياز مردم جامعه به خدمات درمانى مىشود و در نتيجه، نياز به تخت هاى بيمارستانى هم كاهش خو اهد يافت. توسعه شبكه مراقبتهاى اوليه بهداشتى و ارائه خدمات منسجم ارتقاى سلامت موجب كاهش بسترىهاى غير ضرورى بيماران در بيمارستانها مىشود(اسو."r). همجينين، ادغام مراقبتهاى بهداشتى و خدمات اجتماعى 
عادلانه از خدمات بيمارستانى نيز حائز اهميت است. عوامل اجتماعى، فرهنگى و اقتصادى، نوع و شدت بيمارى و داشتن بيمه سلامت بايه و مكمل بر ميزان استفاده مردم از خدمات وندات

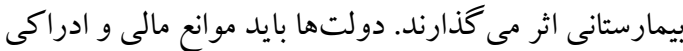
استفاده از خدمات بيمارستانى را برطرف كنند. طرح تحول نظام سلامت ايران، با كاهش يرداخت مستقيم مردم در

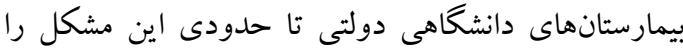

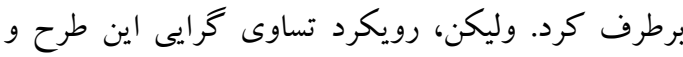
دادن يارانه سلامت به همه بيماران بيمارستانهاى دانشكاهى دولتى، منجر به افزايش تقاضاى القايى از طرف ارائه كننده و مصرفكنده خدمات بيمارستانى، انتقال بار بيماران بيمارستانهاى خصوصى به سمت بيمارستانهاى دانشكاهى بـى دولتى، فشار مالى زياد به سازمانهاى بيمه سلامت و كاهش بهاك

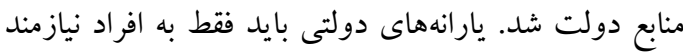
كمكك مالى داده شود. همجِنين، بيمارستانها بايد خدمات كرانقيمت را بر اساس بروتكلهاى تعيين شده ارائه كنند تا كاهش قيمت تمام شده براى بيمار، منجر به افزايش تقاضاى القيى نشود؛ بنابراين، استحقاق سنجى مالى و بالينى بيماران بايد مورد توجه مديران بيمارستانهاى دانشكاهى دولتى قرار

بيمارستان يك سازمان اجتماعى تخصصى بروكراتيك بسيار بيجِيده است. ادارهى جنين سازمان تخصصى نيازمند مديريت تخصصى و بهرهيرى از علم و هنر مديريت خدمات بهداشتى و درمانى است. مديران حرفهاى بهداشت

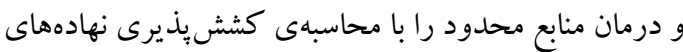
توليد و بيشينى تقاضا به خوبى تخصيص مىدهند. با توجه

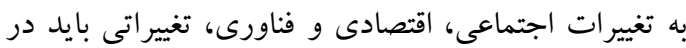

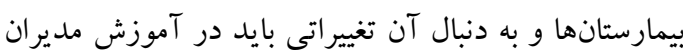
بيمارستانها بهوجود آيد. مديران بايد از دانش بنيادى مديريت و مهارتهاى تفكر استراتزيك،، سيستمى، خلاقانه، جانبى و انتقادى برخوردار شوند تا بتواند بهرهورى بيمارستانهاى كشور را افزايش دهند.
در ارائه خدمات بيمارستانى كشور دارد. بخش خصوصى با

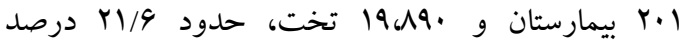
بيمارستانهاى كشور و 19/V\% تختهاى بيمارستانى كشور را در سال هوها تشكيل داده است. ميانگين درصد اشغال تخت بيمارستانهاى خصوصى و خيريه كشور هم 90٪ در سال هوץ| بوده است. بيشتر اين بيمارستانها هم در تهران و مراكز استانها مستقر هستند. از طرف ديخر با شرايط اقتصادى فعلى و مشكلات تأمين مالى بيمارستانها به ويزه بيمارستانهاى خيريه و خصوصى، انتظار مىرود كه مديران

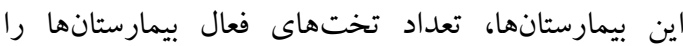
كاهش دهند تا به نوعى از زيانهاى احتمالى بكاهند؛ بنابراين، سياست گذاران نظام سلامت بايد اقداماتى را براى تقويت مشاركت بخش خصوصى در ارائه خدمات سلامت بنابت به ويزه در شهر ستانها بكار گيرند. خيرين و مؤسسات خيريه نقش بسزايى در تأمين مالى، توسعه منابع و ارائه خدمات سلامت در ايران دارند (MF). تعداد كل خيرين سلامت ايران در سال

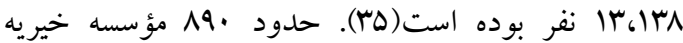
سلامت تا سال 9\$\$ا در كشور در حال فعاليت بودند. مشاركت خيرين در سطح دانشكاههاى علوم بز شكى كشور دهور

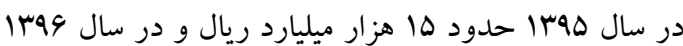
حدود V ال هزار ميليارد ريال بوده است كه صرف احداث بيمارستان، درمانكاه، مركز بهداشتى و درمانى، خانه بهداشت، اورزانس شهرى و بينراهى و ساير نيازهاى حوزه سلامت شده است(4)؛ بنابراين، سياست كذاران و مديران ارشد نظام سلامت با برنامهريزى، سازماندهى، هدايت و نظارت صحيح، بايد از اين فرصت براى تو سعه هدفمند نظام

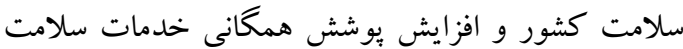

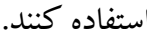
توزيع عادلانه تختهاى بيمارستانى دسترسى جغرافيايى برابر براى مردم جامعه ايجاد مى كند كه شرط لازم براى هدف سلامتى براى همه است، وليكن، كافى نيست. استفاده 


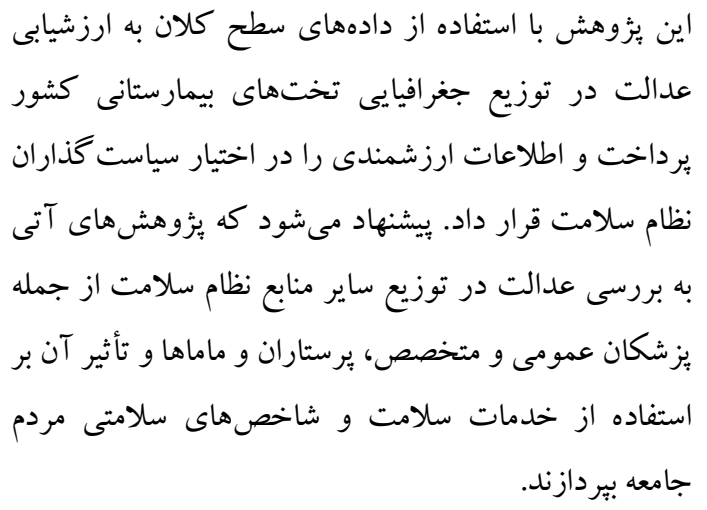

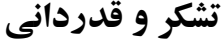

اين مقاله حاصل بخشى از بايان نامه دكتراى مديريت خدمات بهداشتى و درمانى با عنوان اطراحى مدل كنترل

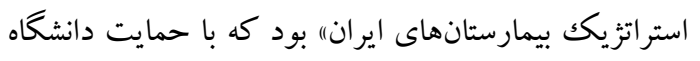
علوم يزشكى و خدمات بهداشتى درمانى تهران اجرا شد.

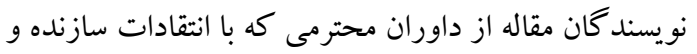
بيان نظرات كارشناسى خود به ارتقاى كيفيت اين مقاله كمك كردند، صميمانه تشكر مى كنند.
نتيجه كيرى

اكرجه شاخص تعداد تختهاى بيمارستانى ايران (ه/ ا تخت

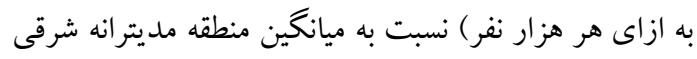

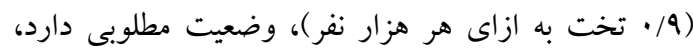

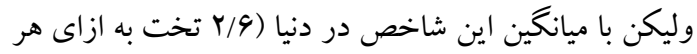

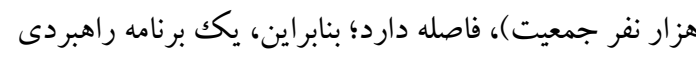
براى مديريت تختهاى بيمارستانى كشور بايد تدوين شود. توزيع تختهاى بيمارستانى در استانهاى ايران نسبتاً عادلانه

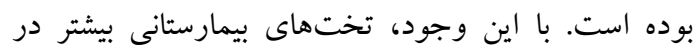

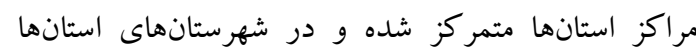

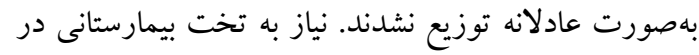

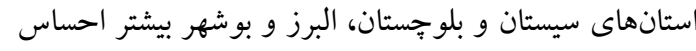
مىشود. افزايش كارايى بيمارستانهاى موجود و تشويق مشاركت بخش خصوصى به ساخت بيمارستان در اين

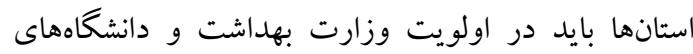
علوم يز شكى و خدمات بهداشتى درمانى كشور قرار گيرد.

\section{References}

1. World Health Organization. World Health Report 2000 - Health systems: improving performance. Geneva. 2000.

2. Culyer AJ. Equity - some theory and its policy implications. J. Med. Ethics. 2001; 27 (4): 275-283. 3. Mosadeghrad AM, Hashempour R, Veisy M. Equity in geographical distribution of medical specialists in Iran. hbrj. 2017; 3 (1): 25-37.

4. Burau V, Blank R. Comparing health policy: an assessment of typologies of health systems. Journal of Comparative Policy Analysis. 2006; 8(1):63-76.

5. World Health Organization, World Health Statistics: Monitoring health for the SDGs, 2018.

6. Fink G, Günther I, Hill K. Slum residence and child health in developing countries. Demography. 2014; 51:1175-97

7 World Health Organization, World health statistics monitoring health for the SDGs. 2016.

8. Paciorek CJ, Stevens GA, Finucane MM, Ezzati M on behalf of the Nutrition Impact Model Study Group (Child Growth). Children's height and weight in rural and urban populations in low-income and middle-income countries: a systematic analysis of population-representative data. Lancet Glob Health. 2013;1(5):300-9.

9. Chu TB, Lui TC, Chen CS, Tsai YW, Chiu WT. Household out-of-pocket medical expenditures and National Health Insurance in Taiwan: income and regional inequality. BMC Health Serv Res. 2005;5:60-9. 
10. Saxena S, Eliahoo J, Majeed A. Socioeconomic and ethnic group differences in self-reported health status and use of health services by children and young people in England: cross sectional study. Br. Med. J. 2002; 325 (7363): 520.

11. Mosadeghrad AM. Patient choice of a hospital: Implications for health policy and management, Int J Health Care Qual Assur. 2014; 27 (2): 152-164.

12. Mosadeghrad AM, Ferlie E. Total quality management in healthcare. Management innovations for healthcare organizations: adopt, abandon or adapt. 2016:378-96.

13. Mosadeghrad AM. Essentials of healthcare organization and management. 1st Edition, Tehran: Dibagran Tehran; 2015.

14. Rechel B, Wright S, \& Edwards N. Investing in hospitals of the future. WHO Regional Office Europe. 2009.

15. Barnum H, Kutzin J. Public hospitals in developing countries: resource use, cost, financing. Baltimore: Johns Hopkins University Press; 1993.

16. Iran Ministry of Health, Hospital beds statistics. Ministry of Health, Treatment deputy. 2019. Available at: http://avab.behdasht.gov.ir/rbp2/Rbp2/default/Default_body.asp [Access date 30/04/2019]

17. Iran statistics centre, population statistics. Available at: https://www.amar.org.ir/ [Access date 30/04/2019]

18. Wagstaff A, Paci P, van Doorslaer E. On the measurement of inequalities in health. Soc Sci Med. 1991;33:545-57.

19. Reza M, Joseph LG. A cautionary note on estimating the standard error of the Gini index of inequality. Oxf Bull Econ Stat. 2006;68:385-90.

20. Ceriani L, Verme P. The origins of the Gini index: extracts from Variabilità e Mutabilità (1912) by Corrado Gini. J Econ Inequal. 2012;10(3):421-43.

21. Lorenz MO. Methods of measuring the concentration of wealth. Publications of the American statistical association. 1905;9(70):209-19.

22. Roemer MI. Bed supply and hospital utilization: a natural experiment. 1961; 35: 36-42.

23. Mosadeghrad AM, Esfahani P, Nikafshar M. Hospitals' efficiency in Iran: A Systematic Review and Meta-Analysis of Two Decades of Research, Payavard. 2017; 11(3): 318-31.

24. Mosadeghrad AM, Dehnavi H. Evaluation of hospital performance in Iran: A systematic review and meta-analysis. Payesh. 2018; 17 (6):603-615.

25. Safi-Arian R \& Shahhoseini R. Assessment of technical efficiency of hospitals under Hamadan University of medical sciences on performance indicators and data envelopment analysis model 2010. Pajouhan Scientific Journal. 2013; 11(2): 27-34.

26. Goudarzi R, Rjabi Gilan N, Ghasemi SR, Reshadat S, Askari R \& Ahmadian M. Efficiency measurement using econometric Stochastic Frontier Analysis (SFA) method, case study: Hospitals of Kermanshah university of medical sciences. J. Kermanshah univ. med. Sci. 2014; 17(10): 666-72.

27. Mosadeghrad AM, Esfahani P, Afshari M. Strategies to improve hospital efficiency in Iran: A scoping review. Payesh. 2019; 18 (1):7-21.

28. Mosadeghrad AM. Developing and validating a total quality management model for healthcare organizations", The TQM Journal. 2015; 27 (5): 544 - 564.

29. Mosadeghrad AM. Verification of a quality management theory: Using a Delphi study. Int J Health Policy Manag. 2013; 1 (4): 261-271.

30. Da Silva EN, Powell-Jackson T. Does expanding primary healthcare improve hospital efficiency? Evidence from a panel analysis of avoidable hospitalisations in 5506 municipalities in Brazil, 2000 2014. BMJ Glob Health. 2017;2(2):e000242.

31. Rosano A, Loha CA, Falvo R, Van der Zee J, Ricciardi W, Guasticchi G, De Belvis AG. The relationship between avoidable hospitalization and accessibility to primary care: a systematic review. Eur J Public Health. 2012; 29;23(3):356-60.

32. Landi F, Gambassi G, Pola R, Tabaccanti S, Cavinato T, Carbonin P, Bernabei R. Impact of integrated home care services on hospital use. J Am Geriatr Soc. 1999;47(12):1430-4.

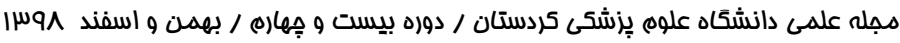


33. Etemadian M, Mosadeghrad AM, Mohaghegh Dolatabadi MR, Dehnavi H. The challenges of public private partnership in hospital operations: A case study. Payesh. 2019; 18 (2):127-148.

34. Mosadeghrad AM, Tajvar M. Ehteshami F. Donors' participation in financing health system of Iran. Hakim Health Sys Res. 2019; 22 (1):26-42.

35. Bayat A. Introduction of the health charity assembly, Statistical Report 2015. Tehran: 2015. Available at: http://www.salamat charity.ir/images/Amar/report94.pdf [Access date 30/04/2019]

36. Ayazi MH, Jamali M, Javadi MH, Hoseini nejad J, Rafiefar Sh, Zamani Garmsiri S, et al. Deputy for social affair at a glance, Ministry of health and medical education. Barta publication, Tehran. 2018; p.18. 